\title{
Da intolerância religiosa aos Direitos Humanos
}

Antonio Baptista Gonçalves ${ }^{1}$

\section{Resumo}

A religião é a responsável direta por temas como proselitismo, laicismo e laicidade. Portanto, compreender como eram as relações religiosas nos tempos antigos trará o arcabouço de conhecimento necessário para apresentar a intolerância religiosa professada e praticada em larga escala, principalmente pelas religiões ocidentais. Assim, a liberdade religiosa que hoje se propaga e se busca por meio dos elementos protetivos de Direitos Humanos é fruto direto de uma evolução histórica da própria religião, bem como de sua influência na vida das pessoas e da disputa pelo poder entre o Estado e a Igreja. Dessa forma, a tolerância será o resultado de toda uma construção dos organismos internacionais em defesa dos direitos do homem, ou os Direitos Humanos.

Palavras-chave: Intolerância. Religião. Direitos Humanos.

\section{Introdução}

A liberdade religiosa passou por momentos delicados na história. E, em grande parte, tais atos foram fomentados pela atuação da própria Igreja em uma nítida disputa pelo poder com o Estado, quando, em verdade, a questão central deveria ser a fé e a função religiosa em primeiro plano. Contudo, a Igreja, por meio

\footnotetext{
1 Membro da Associação Brasileira dos Constitucionalistas; Pós-Doutorando em ciência da Religião - PUC/SP; Doutor e Mestre em Filosofia do Direito - PUC/SP; Especialista em International Criminal Law: Terrorism's New Wars and ICL's Responses - Istituto Superiore Internazionale di Scienze Criminali; Especialista em Direito Penal Econômico Europeu - Universidade de Coimbra; Pós-graduado em Direitos Fundamentais/Universidade de Coimbra; Pós-graduado em Direito Penal - Teoria dos Delitos/Universidade de Salamanca; Pós-graduado em Direito Penal Econômico/Fundação Getúlio Vargas - FGV; Bacharel em Direito pela Universidade Presbiteriana Mackenzie.
} 
de seus líderes, influenciou sobremaneira nas atitudes políticas dos Estados, amealhando, assim, poder, influências, riquezas e posses.

Somado a isso, a Igreja, em especial a cristã, propalou e disseminou a intolerância religiosa mediante o proselitismo da Santa Inquisição, um dos processos de perquirição e julgamento mais sangrentos que a história religiosa conheceu.

A resposta da sociedade foi impor o laicismo às religiões ocidentais, em especial à cristã. Esse bloqueio estatal, como resposta às inferências religiosas, perdurou até as duas grandes Guerras Mundiais, quando o enfoque passou a ser outro. De tal sorte que, analisar a evolução histórica desta relação com a religião e a intolerância, ainda que de forma sintética, será fundamental para compreender qual a relação da tolerância religiosa com esta evolução e, até mesmo, com o surgimento dos Direitos Humanos.

\section{A influência da religião na vida humana}

A religião, ou melhor, a crença na existência de forças ou entidades sobrehumanas responsáveis pela criação, ordenação e sustentação do universo, se mostra presente no cotidiano da sociedade há mais tempo do que a existência das religiões com mais quantidade física de adeptos e seguidores ${ }^{2}$ (Cristianismo, Islamismo, Hinduísmo, Budismo, Judaísmo) que conhecemos nos dias correntes. De acordo com Jean Delumeau,

As religiões têm um passado muito longo. Os homens de Neandertal, que viveram entre 95000 e 35000 a.C. e cujos vestígios foram encontrados da França ao Oriente Médio, já prestavam homenagem a seus mortos. A mais antiga sepultura até hoje conhecida provém de uma gruta situada perto de Nazaré e foi descoberta em 1969: é de um adolescente de aproximadamente 14 anos. Revela um verdadeiro ritual: escavação e arrumação da cova, colocação do corpo em posição intencional e oferendas de significado simbólico (DELUMEAU; MELCHIOR-BONNET 2000, p. 17).

\footnotetext{
2 Cristãos 32,84\%, Muçulmanos 19,9\%, Hindus 13,29\%, Budistas 5,92\% e Judeus 0,23\%.
} 
E se faz necessário apresentar que a relação do homem com o culto a uma divindade igualmente se modificou com o transcorrer do tempo. O modelo monoteísta seguido e difundido por religiões como o Cristianismo, Islamismo e Judaísmo, não era o predominante em priscas eras, ${ }^{3}$ mas sim, um culto a vários deuses, isto é, o politeísmo, o mais puro conceito de liberdade religiosa desde o começo dos tempos (O’DONNELL, 2007, p. 10).

David Hume (2005, p. 23) afirma ser um fato incontestável que toda a humanidade, há 1700 anos, era politeísta, ${ }^{4}$ e vai mais além (2005, p. 24):

Até onde a escrita ou a história penetram, a humanidade, nos tempos antigos, parece ter sido universalmente politeísta. Afirmaremos que em tempos mais remotos ainda, antes do conhecimento da escrita ou da descoberta das artes e das ciências, os homens professavam os princípios do puro monoteísmo? Ou seja, que quando eram ignorantes ou

3 "Há uma polêmica sobre se o monoteísmo, a crença em um só Deus, era uma forma original de religião. Essa é uma postura assumida há muito tempo pelos judeus, cristãos e muçulmanos de todo o mundo, de acordo com a história da criação, do primeiro homem e da primeira mulher, Adão e Eva. São Paulo aproveitou esse argumento e disse que o politeísmo (a crença em muitos deuses) era uma degeneração, resultado de corações embrutecidos porque as pessoas haviam se afastado de Deus. Essa visão foi rejeitada pelos estudiosos dos séculos XIX e XX, baseados na perspectiva evolucionária” (O’DONNELL, 2007, p. 10).

4 Politeísmo é um termo culto, documentado na França a partir do século XVI, usado, no sentido teológico, em oposição a "monoteísmo". Composto com o sufixo - teísmo, como monoteísmo, é uma construção moderna derivada do vocábulo grego polýs, "muitos", e theós, "deus". No âmbito histórico-religioso, o termo politeísmo determina um "tipo" de religião e, portanto, classifica e descreve formas religiosas que admitam a coexistência de mais de uma divindade, às quais se devota um culto. Consequentemente, para poder classificar uma religião como politeísta, ela deve admitir a noção de "divindade" ou pressupor uma noção análoga a esta e por ela assimilável. Isto é, ela requer ao menos uma ideia de transcendência dos seres sobre-humanos diante da realidade humana, em relação à qual, todavia, participam ativamente. É bastante provável que essa ideia tenha se originado na região mesopotâmica e que de lá tenha sido exportada por um processo de difusão (SCARPI, 2004, p. 12). 
bárbaros descobriram a verdade, mas que caíram no erro assim que adquiriram conhecimento e educação ${ }^{5}$

E, gradualmente, essa visão e adoração a vários deuses perdeu intensidade e deu lugar a um cultuar singular, a um único Deus, em uma visão monoteísta, como ao modelo adotado pelos cristãos, muçulmanos, judeus etc. (ZENGER, 2009, p. 19). ${ }^{6} \mathrm{O}$ que não significa que o culto politeísta deixou de existir, pois o Hinduísmo tem por sua essência a adoração a vários deuses.

Assim, com o transcorrer do tempo, o que se torna quase que uma premissa indiscutível é a aceitação dos povos acerca da presença de uma “força”, um "poder”,

5 E conclui: "Essa afirmação contradiz não somente toda a aparência de probabilidade, mas também nossos conhecimentos atuais a respeito dos princípios e opiniões das nações bárbaras. As tribos selvagens da AMÉRICA, ÁFRICA e ÁSIA são todas idólatras. Não há uma única exceção a essa regra. De tal modo que, se um viajante se mudasse para uma região desconhecida e encontrasse ali habitantes versados nas ciências e nas artes - ainda que tal hipótese haja probabilidade de eles não serem monoteístas -, nada poderia concluir sobre esse tema sem antes realizar uma investigação mais profunda. Mas se ele os considerasse ignorantes e bárbaros, poderia afirmar, antecipadamente, com mínimas possibilidades de erro, que eram idólatras" (HUME, 2005, p. 24).

6 "Em algum momento no decorrer da Antiguidade - as datas oscilam entre o final da Era do Bronze e o final da Antiguidade - ocorreu uma mudança que foi mais decisiva para o mundo do que todas as alterações políticas com as quais convivemos hoje. Trata-se da mudança das religiões 'politeístas' para aquelas 'monoteístas', de religiões de culto para religiões de livros, de religiões específicas de determinadas culturas para religiões universais, em suma: de religiões 'primárias' para religiões ‘secundárias”' (ZENGER, 2009, p. 19). 
um "ser superior", invisível, "Deus,", os nomes variam de acordo com a religião ou o entendimento religioso. ${ }^{8}$

E esse culto a um único Deus propiciou uma série de interpretações variadas sobre qual o Deus que deve ser cultuado. E assim se disseminou a pluralidade religiosa com o surgimento de várias religiões que cultuam um único Deus, porém, diferentes entre si, seja na forma do culto ou na própria divindade.

7 A revista Superinteressante produziu uma edição especial, na qual chamou de Deus uma biografia: Cada sociedade vê a figura do Criador à sua maneira. Cada indivíduo, até. Para Einstein, Ele era as leis que governam o tempo e o espaço - a natureza em sua acepção mais profunda. Para os ateus, Deus é uma ilusão. Para o papa Bento XVI, é o amor, a caridade. "Quem ama habita Deus; ao mesmo tempo, Deus habita quem ama", escreveu em sua primeira encíclica. Pontos de vista à parte, toda cultura humana já teve seu Deus. Seus deuses, na maioria dos casos: seres divinos que interagiam entre si em mitologias de enredo farto, recheadas de brigas, lágrimas, reconciliações. Os deuses eram humanos. Mas isso mudou. A imagem divina que se consolidou é bem diferente. Deus ganhou letra maiúscula na cultura ocidental. Os panteões divinos acabaram. Deus tornou-se único. É o Deus da Bíblia, Javé, o criador da luz e da humanidade. O pai de Jesus. Essa concepção, que hoje parece eterna, de tanto que a conhecemos, não nasceu pronta. Ela é fruto de fatos históricos que aconteceram antes de a Bíblia ter sido escrita. O próprio Javé já foi uma divindade entre muitas. Fez parte de um panteão do qual não era nem chefe. $\mathrm{O}$ fato de ele ter se tornado o Deus supremo, então, é marcante: se fosse entre os deuses gregos, seria como se uma divindade de baixo escalão, como o Cupido, tivesse ascendido a uma posição maior que a de Zeus. A história de Javé, a figura que começou como um pequeno deus do deserto e depois moldaria a forma como cada um de nós entende a idéia de Deus, não importando quem ou o que Deus seja para você.

8 David Hume (2005, p. 43) uma vez mais: "A única questão teológica sobre a qual encontramos um consenso quase universal entre os homens é que existe um poder invisível e inteligente no mundo. Mas se esse poder é supremo ou subordinado, se está nas mãos de um único ser ou distribuído entre vários, quais atributos, qualidades, conexões ou princípios de ação devem ser atribuídos a esses seres? Sobre todas essas questões existe a mais completa divergência nos sistemas teológicos populares". 
Nesse movimento, três religiões despontaram sobremaneira: Judaísmo, ${ }^{9}$ Is-

9 "Há 4.000 anos, os judeus (ou hebreus) se uniram como uma nação. Abraão, Isaac e Jacó, nas antigas histórias judaicas, eram os líderes dessa nova nação. Mais tarde, os judeus foram dominados pelos egípcios e forçados a partir para o Egito e trabalhar como escravos. Depois de muito tempo, foram salvos por um líder chamado Moisés que os conduziu para fora do Egito, para a terra hoje conhecida como Israel. Isso aconteceu cerca de 1.250 anos antes do nascimento de Jesus Cristo" (CHARLESWORTH; INGPEN, 2003, p. 17).

Segundo O’Donnell (2007, p. 89), “Os judeus acreditam que foram eleitos por Deus; que foram chamados por Deus para aprender suas leis e representar o seu caminho entre as demais nações. Eles estão ligados a Deus pela aliança feita com Moisés, seu grande profeta e líder espiritual. Uma aliança é um compromisso solene, um juramento de união entre duas partes. A Lei foi dada a seu povo e sua parte na aliança é seguir a Lei: Deus libertou seu povo da escravidão no Egito, e demonstrando gratidão, eles devem seguilo. A responsabilidade desse chamado ficou clara com o passar do tempo. Eles devem ser "a luz das nações" e os propósitos de Deus frustrar-se-iam se seu povo abandonasse suas leis. As histórias dos ancestrais têm suas origens no que hoje é o território conhecido como Israel, mas que naquela época era chamado de Canaã. As tribos ocuparam o topo da montanha da Judéia e transformaram Jerusalém em sua capital. Uma sucessão de reis os manteve unidos durante anos. O mais famoso destes reis foi David. O nome inicial das tribos era 'hebreus', termo que significa viajante ou errante. Literalmente o significado é 'do outro lado' ou, em outras palavras, do outro lado do Rio Tigre e do Rio Eufrates. As histórias dos ancestrais mostram as tribos viajando da área do golfo até a região de Canãa. 'Hebreu' também pode significar o mesmo que o antigo termo habiru, aqueles que não se estabelecem. Seus ancestrais, às vezes são chamados 'arameus'. $\mathrm{O}$ termo Israel foi introduzido logo no início do ciclo de sagas ancestrais; foi o nome dado a seu ancestral Jacó, depois da revelação de Deus. Os hebreus tornaram-se israelitas, depois o termo 'judeu' passou a indicar aquele que vem da terra da Judeia. Essa região ficava ao sul do reino e continuou existindo mesmo depois que os assírios conquistaram a região norte. Então, hebreu, israelita ou judeu são três termos que designam o mesmo povo. Ao longo dos anos apareceram diferentes tipos de Judaísmo. Havia sacerdotes e sacrifícios desde a época do Templo, e depois da queda de Jerusalém, em 70 d. C., começaram a existir os rabis e as sinagogas. Os rabis são especialmente treinados na Lei, a Torá, e nas tradições orais de seu povo, a Halachá". 
lamismo $^{10}$ e Cristianismo. ${ }^{11}$

10 "Maomé era árabe. Nasceu por volta de 570 d.C., na cidade de Meca, na Arábia Saudita. Maomé conhecia o judaísmo e o cristianismo. Aos quarenta anos, recebeu uma mensagem de Deus pedindo-lhe para ser seu profeta, ou mensageiro" (CHARLESWORTH; INGPEN, 2003, p. 30). Para O’Donnell (2007, p. 142), “A fé do Islã é considerada pelos muçulmanos como a fé original, a fé revelada. Eles acreditavam que ela foi revelada a Adão e aos profetas, incluindo Abraão, Moisés, David e Jesus. Mais tarde, no começo do século VII d.C., surgiu um novo profeta na Arábia, que confirmava as profecias anteriores. Suas mensagens proféticas foram apreendidas na memória e mais tarde foram reunidas no Alcorão. A palavra "Islã"vem do verbo $s l m$ em árabe e significa paz ou submissão. A palavra tem sentido duplo, mas os muçulmanos acreditam que devem se submeter à vontade de Deus (Alá), para encontrar a paz. A palavra "muçulmano" também deriva da mesma raiz significando aquele que se submete (a Deus). A primeira surata (seção) do Alcorão, a oração Fattiha, fala sobre essa submissão e o caminho para a paz. A palavra "Alá" é o termo árabe para Deus. Hoje em dia ela significa "o Deus" ou "o Deus único", mas as tribos árabes já veneraram muitos deuses, em um panteão em que Alá era o deus principal, juntamente com sua consorte, Allat e suas três filhas. Muhammad (Maomé) ouviu falar do Deus único dos judeus e dos cristãos em suas viagens, e identificou Alá com esse Deus único, rejeitando sua consorte e rejeitando a hipótese de ele ter uma descendência".

11 "A religião cristã teve início com Jesus Cristo. Jesus era judeu e vivia na região hoje conhecida como Israel. Seus primeiros seguidores também eram judeus. O cristianismo desenvolveu-se dentro do judaísmo, sendo, portanto, uma ramificação dessa religião. Mais tarde, quando o cristianismo tornou-se a religião da Europa, os cristãos eram, na maioria, não-judeus - gregos, romanos e outros povos vizinhos" (CHARLESWORTH; INGPEN, 2003, p. 22). De acordo com O’Donnell (2007, p. 117), “O Cristianismo é uma crença religiosa baseada no "Cristo", que se acredita ser Jesus de Nazaré. Jesus foi um judeu que viveu no século I d.C.. Os cristãos acreditam que ele era Deus e homem ao mesmo tempo, a unidade sublime da terra com o céu". O mesmo autor prossegue: "O Cristianismo começou como um movimento judeu no Oriente Médio. Jesus era um Galileu, que viveu em um lugar afastado no Império Romano, entre os anos 4 a.C. e 33 d.C. A fé que ele inspirou espalhou-se por todo o Império Romano, ganhando status de religião oficial no século 4 d.C.. Séculos de veneração ao imperador e aos deuses pagãos foram descartados em favor do profeta e do carpinteiro do Ocidente. A fé também alcançou a antiga Pérsia, China e Índia, o mundo grego e a região que depois se tornaria a Europa. O Cristianismo é uma fé construída sobre um paradoxo. Alega-se não somente que Deus poderia se tornar homem, mas também que um homem crucificado podia ser saudado como Salvador e Senhor. A crucificação era uma punição bárbara que os romanos aplicavam nos criminosos e rebeldes e morrer dessa maneira era uma desonra. Mas os cristãos acreditavam que aquele homem que aparentemente havia falhado tão fragorosamente era o mesmo que depois se tornaria o mais sublime de todos. Os valores do Cristianismo giram em torno da humildade, do perdão e da graça divina (ato de generosidade de Deus para com o homem, mesmo quando este não alcançou o mérito necessário por meio das boas ações)". 
Esse cultuar de maneira distinta o mesmo Deus ou um Deus diferente propiciou a busca dos líderes religiosos em difundir a sua própria religião entre as pessoas e, assim, amealhar novos fiéis. Com isso, existe a possibilidade concreta de migração de fiéis de uma religião para outra, ou na adesão de uma pessoa, até então, sem religião, por uma crença determinada.

E é nessa relação entre a aceitação das pessoas e a difusão de ideias por um líder religioso que os problemas despontam, pois, o objetivo fulcral de uma religião é cultuar o(s) Deus(es) em que acreditam, porém, atraindo a maior quantidade de fiéis possível. No entanto, o objetivo não é apenas atrair novos fiéis, pois os outros líderes religiosos também usaram de tal estratagema. Ao mesmo tempo, o líder religioso também deve se preocupar em manter seus próprios fiéis “imunes” às propagandas das outras religiões.

Então, proteger-se e atrair os demais ao mesmo tempo, fazer sua religião crescer diminuindo as demais. A esse “teste" da própria fé e dos participantes da fé alheia denomina-se proselitismo.

\section{0 proselitismo e seu impacto positivo e negativo}

Proselitismo. ${ }^{12}$ Zelo ou diligência em fazer prosélitos: o proselitismo religioso. Prosélito. ${ }^{13}$ Do grego proselytos, pelo latim eclesiástico proselytus). 1. Pessoa que se converteu a uma religião. - 2. Pessoa que abraçou uma seita, uma doutrina, um partido; adepto, partidário. - 3. Pessoa que abjurava suas crenças para adotar a religião judaica.

Proselitismo, então, deve ser entendido como o convencimento de uma pessoa a trocar de religião ou, caso não possua uma, a aderir a uma determinada

\footnotetext{
${ }^{12}$ Proselitismo. 1. Atividade ou esforço de fazer prosélitos, catequese, apostolado. 2. Conjunto de prosélitos.

${ }^{13}$ Prosélito. 1. Entre os antigos hebreus, indivíduo recém-convertido à religião judaica. 2. Pessoa que foi atraída e que se converteu a uma outra religião, uma seita, uma doutrina ou um partido, um sistema, uma idéia, etc. Adeptos, sectário, partidário.
} 
crença. E podemos citar duas, dentre várias religiões que possuem essa prática: Testemunhas de Jeová ${ }^{14}$ e Mórmons. ${ }^{15}$

O proselitismo é a forma encontrada pelas religiões tanto no papel dominante, como maioria, ou como minoria religiosa, para atrair novos fiéis à sua crença. Para isso, uma gama de estratégias e formas de apresentação dessa crença é desenvolvida. Tudo no intuito de convencer o indivíduo de que a sua religião não é a adequada e que se sentirá muito melhor física, moral, psicológica e espiritualmente se migrar e adotar a nova palavra.

O proselitismo sempre foi um importante catalisador dos ideários das igrejas, independentemente da religião escolhida. Ao longo de uma missa, quando o padre realiza o seu sermão e elogia a sua religião e enfatiza uma série de passagens, do que estamos falando senão de proselitismo? Além disso, temos de incluir as manifestações públicas de fé, as viagens apostólicas e a forma como as igrejas se utilizam de seus mártires como forma de captação da fé alheia.

Em tempos presentes, o proselitismo ganhou novas armas: a internet, os programas de rádio, os programas de televisão, jornais especializados etc. Todos eles, meios de comunicação em massa com o objetivo único de disseminar a dou-

${ }^{14}$ A comunidade religiosa Testemunhas de Jeová foi fundada no EUA no final do século XIX por integrantes da sociedade Torre de Vigia de Sião, cujo primeiro presidente foi Charles T. Russel. Até o início da década de 1930, eram conhecidos como Estudantes da Bíblia, passando então a ser denominados de Testemunhas de Jeová. Filosofia e guerra. Revista Conhecimento Prático Filosofia, n. 26, p. 21.

${ }^{15}$ A comunidade religiosa Mórmons inicialmente era conhecida como A Igreja de Jesus Cristo dos Santos dos Últimos Dias. Foi organizada em 6 de abril de 1830, em Fayette, Nova York. Entre os seis primeiros membros estava Joseph Smith, primeiro profeta e presidente da Igreja Restaurada. Em 1823, Joseph foi mandado, por um mensageiro celestial chamado Morôni, a um monte perto de Palmyra. Lá mostrou a Joseph placas de ouro que continham a história secular e religiosa de uma antiga civilização americana. Quatro anos mais tarde, Joseph teve permissão para tirar as placas da colina e traduzi-las para o inglês. $\mathrm{O}$ volume traduzido, que leva o nome de um dos antigos profetas e historiadores que havia guardado os registros, foi publicado como o Livro de Mórmon. O apelido da Igreja "Mórmon" vem do título deste livro sagrado.O Livro de Mórmon contém a história de várias civilizações da América antiga, entre cerca de 2200 a.C e 420 d.C. O volume inclui um relato do ministério de Jesus Cristo no continente americano, depois de sua ressurreição. Disponível em: <www.mormons.com.br>. Acesso: 13 fev. 2011. 
trina e conquistar novas pessoas à crença religiosa. No entanto, não apenas de aspectos positivos temos o proselitismo, e, assim, importante analisar o proselitismo negativo.

Sobre o proselitismo negativo, ${ }^{16}$ temos dois pontos controvertidos: o proselitismo em si e a relação do proselitismo com os Estados que adotam uma religião de forma oficial ou que são influenciados politicamente por ela.

O primeiro aspecto se refere ao proselitismo propriamente dito. Ocorre que essas tentativas de conversão nem sempre cumprem com os ritos ideais de lisura e respeito à religião alheia. $\mathrm{O}$ ponto que cerca o proselitismo não é a liberdade religiosa e nem o convertimento de pessoas a sua crença religiosa. O problema impera na forma como alguns procedimentos são feitos, pois, transformam-se em verdadeiras práticas de (in)tolerância religiosa, especialmente em locais em que o Estado adota uma religião de forma oficial. ${ }^{17}$

Em Estados que não são considerados laicos, ${ }^{18}$ esse posicionamento é considerado como prejudicial para o governo, pois, a conversão de seus fiéis ou a propagação das ideias diferentes da religião oficial do País podem perturbar a ordem e, quem sabe, incitar a população, logo, representam uma ameaça às pretensões estatais. Os "representantes" do governo tendem a reprimir essas minorias religiosas, como forma de assegurar a integridade religiosa do próprio Estado, o que, de forma alguma, justifica ou, tampouco, autoriza a intolerância religiosa. Com isso, a liberdade religiosa e o livre direito de circulação e de pensamento já foram prejudicados.

${ }^{16} \mathrm{O}$ Brasil sofreu o proselitismo negativo quando os jesuítas, por meio de suas missões, praticamente obrigaram os índios a se converterem e a aceitarem a sua nova crença, o cristianismo, sem se importar com os próprios desejos ou anseios da comunidade.

17 "A actuação do Estado face ao proselitismo encontra-se estritamente ligada à protecção concedida à liberdade religiosa e aos direitos do homem, o que depende em última análise do regime político perfilhado e mesmo da confissão religiosa dominante" (GUERREIRO, 2005, p. 180).

${ }^{18}$ Mesmo o Estado laico pode adotar uma postura restritiva acerca do proselitismo, se for perceptível que a liberdade de crença do próprio Estado está prejudicada e se faz necessária uma intervenção estatal para assegurar os direitos da coletividade. França e Espanha, inclusive, possuem respostas penais para as atividades abusivas derivadas do proselitismo. 


\section{Religião e (in)tolerância}

O proselitismo é o exemplo de que as próprias religiões podem ultrapassar a lisura e a cordialidade das relações que elas professam para manter os fiéis em seus quadros e, ainda, retirar alguns de outro culto. $\mathrm{E}$ ao acrescentar mais um elemento - o Estado, temos o cenário a ser analisado em termos de tolerância religiosa: $\mathrm{o}$ povo, a Igreja e o Estado.

O tema religião por si só já é espinhoso. Tente definir religião, ou melhor, pergunte a dez pessoas aleatoriamente o que vem a ser religião para cada uma delas e lhe asseguramos: haverá dez respostas diferentes. E a existência de uma complexidade acerca da definição da religião também gera controvérsias acerca de sua aceitação, pois, no cenário global, a religião é vista de forma muito diversa.

A Igreja em uma busca pela consolidação de uma soberania e de um poder teve como escopo buscar não apenas o seu espaço religioso, mas também, exercer uma influência política, para assim, ter a força sobre a coletividade. Com isso, houve uma confusão de interesses, assim, o objetivo religioso e a busca para levar a palavra divina se mesclaram a pretensões terrenos e, principalmente, à ratificação de força que se converteriam em acúmulo de riquezas, em um segundo momento.

A Igreja passou a se relacionar intrinsecamente com o Estado e o resultado foi uma confusão entre as partes, pois o Estado teve tanta influência da Igreja que as decisões passaram a ser subordinadas à vontade da Igreja, independente da religião A, B ou C; foi assim com o Judaísmo, com o Cristianismo e com o Islamismo.

Quando essa disputa por poder não aflige nenhuma das partes envolvidas, então, tem-se a paz e, por conseguinte, a tolerância religiosa. ${ }^{19}$ No entanto, a Igreja, em sua busca por amealhar novos fiéis, nem sempre de forma amistosa, como no

\footnotetext{
${ }^{19}$ Particularmente não gostamos do termo tolerância religiosa, pois, mais parece que a religião alheia não é respeitada, mas sim suportada, e esse não é o objetivo de um Estado laico e, muito menos deve ser a atitude de seus membros. Tolerância parece muito mais um sentimento de que a pessoa, não possuindo alternativa, irá respeitar o próximo, por enquanto, quase que uma manifestação latente de um sentimento de preconceito religioso e descontentamento que, a qualquer momento, poderá vir à tona.
} 
caso das cruzadas, ${ }^{20}$ professou mais a intolerância do que os preceitos religiosos fundamentais.

A história nos mostra que a relação entre Estado e Igreja sempre foi próxima, em especial, com o advento do cristianismo; contudo, a influência da religião é muito maior do que a existência da própria Igreja, visto que no Egito antigo, bem como na Grécia, não se fazia uma nítida distinção entre o domínio religioso e o Estado em si.

${ }^{20}$ As cruzadas foram movimentos religiosos, políticos e militares, liderados pela Igreja Católica, apoiados e patrocinados pela nobreza europeia, com a finalidade de dominar a cidade de Jerusalém, considerada "santa" por judeus, cristãos e muçulmanos e lugar de peregrinações para estes povos. Quando Jerusalém foi tomada pelos turcos otomanos, no ano de 1071, por estes serem muçulmanos e intolerantes, proibiram aos cristãos as peregrinações aos lugares sagrados. Por essa razão e pela crise do feudalismo europeu, em 1095, o papa Urbano II conclamou a população a defender o cristianismo contra os infiéis "árabes muçulmanos", afirmando ser esta a vontade de Deus (WOLOSZYN, 2009, p. 4748). Os métodos e a rotina dos membros das cruzadas na maioria das vezes eram cruéis e violentos e o que importava era o objetivo final, para que o leitor tenha uma ideia mais concreta apresentaremos abaixo o relato acerca da primeira cruzada, que ocorreu muito antes da descoberta do Brasil, para que assim, possa ser desfeita a imagem romântica de que as cruzadas foram um movimento pacifico que tinha como condão apresentar a boa palavra da Igreja para os nativos. O relato acerca da primeira cruzada mostrava os indícios dos saques e a grande religiosidade envolta nas missões: “Tendo entrado na cidade, nossos peregrinos perseguiam e massacravam os sarracenos até o templo de Salomão, onde estes estavam reunidos e onde travaram com os nossos o mais furioso combate durante todo o dia, a ponto de ficar banhado de seu sangue o templo inteiro. [...] Os cruzados correram logo por toda a cidade, apoderando-se rapidamente do ouro, da prata, dos cavalos, dos mulos e saqueando as casas. Depois, muito contentes e chorando de alegria, os nossos foram adorar o Sepulcro de nosso Salvador Jesus e se desoneraram da dívida para com ele. Na manhã seguinte, os nossos escalaram o teto do templo, atacaram os sarracenos, homens e mulheres e, puxando a espada, decapitaram-nos. Alguns se lançaram do alto do templo. Vendo isso, Tancredo encheu-se de indignação. Então, os sacerdotes decidiram em conselho que todos dariam esmolas e fariam orações, para que Deus elegesse aquele que ele gostaria que reinasse sobre os outros e governasse a cidade" (DELUMEAU; MELCHIOR-BONNET, 2000, p. 171). 
Sobre o cristianismo, é necessária a sua relação com o Império Romano e, em especial, com o Imperador Constantino, pois o cristianismo ainda claudicava, ${ }^{21}$ até a conversão de Constantino, ${ }^{22}$ quando despontou poucas décadas depois. ${ }^{23}$

O cristianismo teve papel decisivo para inserir a Igreja como protagonista nas relações de governança, como relata J. Vasconcelos:

À medida que o Cristianismo avançava por toda parte do Império Romano, a Igreja Católica foi se organizando como uma poderosa força institucional, salientando-se uma poderosa classe sacerdotal. Com o vazio deixado pela queda do império, a Igreja enveredou por uma política de expansão e destruição das crenças nativas das regiões européias, para tanto usando da persuasão e da força.

Segundo Tércio Sampaio Ferraz Júnior (2003, p. 63-65), após o declínio do Império Romano, a herança espiritual e política do poder político romano passou

${ }^{21}$ Um dos acontecimentos decisivos da história ocidental e até mesmo da história mundial deu-se no ano de 312, no imenso Império Romano. A Igreja cristã tinha começado muito mal esse século IV de nossa era: de 303 a 311, sofrera uma das piores perseguições de sua história, milhares foram mortos. Em 311, um dos quatro coimperadores que repartiam entre si o governo do Império estava decidido a pôr fim àquele estado de coisas, reconhecendo amargamente em sua atitude de tolerância que perseguir não adiantava nada, pois muitos cristãos que tinham renegado sua fé para salvar a vida não tinham voltado ao paganismo. Assim (e esse, à época, foi um assunto de inquietação para um governante), criaram-se buracos no tecido religioso da sociedade (VEYNE, 2010, p. 11).

22 Ora, no ano seguinte, 312, deu-se um dos acontecimentos imprevisíveis: outro dos coimperadores, Constantino, o herói dessa grande história, converteu-se ao cristianismo depois de um sonho ("sob este sinal vencerás"). Por essa época, considera-se que só cinco ou dez por cento da população do Império (70 milhões de habitantes, talvez) eram cristãos (VEYNE, 2010, p. 11).

${ }^{23}$ Oitenta anos mais tarde, como se descobrirá depois, em um outro campo de batalha e ao longo de outro rio, o paganismo será proibido e acabará vencido, sem que tenha sido perseguido. Porque, ao longo de todo o século IV, a própria Igreja, deixando de ser perseguida como o tinha sido ao longo de três séculos, terá o apoio incondicional da maioria dos Césares, tornados cristãos; assim, no século VI, o Império estará quase todo povoado apenas de cristãos (VEYNE, 2010, p. 12). 
para a Religião cristã. ${ }^{24} \mathrm{O}$ cristianismo representou, então, um período de grande prosperidade e influência da Igreja com o Estado, relação esta que trouxe pontos positivos e, em concomitância, uma série de problemas a serem analisados. ${ }^{25}$

\section{A Igreja Católica fomenta a intolerância}

Importante salientar que, a partir deste momento, trataremos dos eventos advindos e decorrentes da influência da Igreja, em especial, no mundo ocidental. Não se aplicando, assim, os fatos a seguir na realidade do mundo árabe e dos seguidores da religião islâmica. A relação da religião com a liberdade religiosa, ou seja,

${ }^{24}$ Paul Veyne (2010, p. 19) relata a virada positiva para o cristianismo com a própria ascensão de Constantino no Império Romano: Em 324, a religião cristã assumia com um golpe único uma dimensão "mundial" e Constantino estaria alçado à estatura histórica que dali em diante seria a sua: ele acabava de esmagar Licínio no Oriente, outro pretenso perseguidor, e assim restabelecia sob seu domínio a unidade do Império Romano, reunindo as duas metades sob o seu cetro cristão. $\mathrm{O}$ cristianismo dispunha daí em diante desse imenso império que era o centro do mundo e que se considerava com a mesma extensão da civilização. Aquilo a que se chamará por longos séculos de Império Cristão, sim, a Cristandade acabava de nascer. Após a queda do Império Romano, toda a edificação cultural e religiosa estava à disposição plena do cristianismo, afinal, o Império ruíra, porém, não o clero ou a religião. Assim, todo o arcabouço de conhecimento, riqueza, influência política, social e ideológica apenas permaneceu. $\mathrm{O}$ resultado foi uma mudança da geografia do planeta, mas não da influência religiosa sobre os novos atores. A Igreja Católica era a referência, e seus líderes tinham nítida influência de poder sobre os governantes. A prosperidade do cristianismo perdurou até o seu movimento mais audacioso: a Inquisição, pois, o que deveria ter sido sua catequese maior foi, em verdade, o princípio de sua ruína e da chegada de um período sombrio em contraponto a toda a prosperidade de séculos de conquistas e expansões.

${ }^{25}$ Para Fürst (2009, p. 97-98), "No cristianismo, as conversões tornaram-se um fenômeno de massa. Não sabemos o que levou a maioria dos cristãos e das cristãs a se converter nem o que vivenciaram, tampouco o que a conversão significou para eles mais tarde, simplesmente porque nada consta das fontes. Contudo, alguns eruditos entre os cristãos manifestaram-se a respeito de sua conversão, e seu relato - geralmente feito de modo bastante comedido - permite-nos observar determinado traço de sua mentalidade religiosa. [...] Será que essa mentalidade condicionava a intolerância e a disposição à violência? Segundo a rigorosa concepção da Igreja da Antiguidade, converter-se significava distanciar-se da maneira mais clara possível do ambiente religioso, social e cultural, relativizar seus valores e suas pretensões, questioná-lo ou rejeitá-lo. Mesmo quando esse procedimento se mostrava profundamente ambivalente - pois os cristãos não podiam simplesmente abandonar o tempo e a cultura em que haviam crescido e em que continuaram a viver e a pensar -, sua mentalidade era determinada, em primeiro lugar, pela delimitação religiosa”. 
a possibilidade de crer em um Deus e de poder cultuá-lo é marcada por passagens que variam de tolerância a intolerância ao longo da História.

Outrossim, a própria Igreja Católica ${ }^{26}$ contribuiu negativamente para o desenvolvimento da intolerância com a Inquisição. ${ }^{27}$ De tal sorte que a intolerância religiosa, a violência e a destruição do patrimônio cultural e religioso de outras sociedades foram o marco desse movimento imposto pela Igreja Católica. ${ }^{28}$ Nessa esteira, a "justificativa” para tamanha atrocidade foi a defesa da própria Igreja Católica ao perseguir os considerados hereges. Foi então criada a Inquisição, na Espanha, “[...] para detectar supostos maus cristãos entre os convertidos" (GREEN, 2011, p. 42). E o resultado seria a pureza da religião católica sem a influência negativa dos maus convertidos ou dos infiéis. ${ }^{29}$

${ }^{26}$ Antes da Inquisição, Jacques Le Goff (2000, p. 39) já aponta traços de intolerância por parte da Igreja cristã: Dos séculos XI, a cristandade torna-se uma "sociedade de perseguição". Beneficiada por um grande desenvolvimento demográfico, econômico, militar, político e cultural, ela quer defender suas conquistas contra aqueles que lhe parecem ameaçá-las; e passa a adotar os instrumentos da repressão e da agressão.

27 Toby Green (2011, p. 30): “É preciso começar reconhecendo a amplitude do tema. De 1478 a meados do século XVIII, a Inquisição foi a mais poderosa instituição da Espanha e de suas colônias nas ilhas Canárias, na América Latina e nas Filipinas. A partir de 1536, no vizinho Portugal e nas colônias portuguesas na África, na Ásia e no Brasil, a Inquisição foi preeminente durante 250 anos. Isso quer dizer que foi uma força significativa em quatro continentes por mais de três séculos; estamos tratando de um período que se estende da unificação da Espanha sob Fernando e Isabel, no século XV, às guerras napoleônicas".

${ }^{28}$ A Inquisição atingiu o ápice da violência na Espanha, nos primeiros cinquenta anos após sua criação, em 1478, período em que, segundo estimativas, cerca de 50 mil pessoas foram julgadas e uma parcela significativa desse número foi queimada na fogueira na condição de relaxados. Em alguns anos, como em 1492, 2 mil pessoas podem ter sido "relaxadas" e outras 2 mil podem ter tido suas efígies queimadas. Aproximadamente setecentas pessoas foram mortas só em Sevilha entre 1481 e 1488, e outras cinquenta em Cidade Real entre 1483 e 1484. Cerca de $10 \%$ de toda a população de Toledo foi julgada pela Inquisição entre 1486 e 1499, e 3\% foi "relaxada” em vida ou em efígie (GREEN, 2011, p. 32-33).

${ }^{29}$ Para compreender o que foi historicamente a Inquisição, é preciso em primeiro lugar definir a heresia, uma vez que a Inquisição foi criada para combatê-la. "Heresia" significa "escolha". Por extensão, assim foi chamada, no cristianismo, toda doutrina incompatível com a fé cristã, que pessoas e grupos "escolhiam" contra a aprovação da Igreja. É normal que uma comunidade, qualquer que seja, não conserve pessoas que nela entraram livremente e que depois se encontravam em grave desacordo com ela. Na Igreja, essa recusa foi chamada "excomunhão", isto é, exclusão da comunhão dos fieis (DELUMEAU; MELCHIORBONNET, 2000, p. 217). 
A Inquisição foi um claro exemplo de proselitismo negativo com o uso da intolerância de forma indiscriminada e atroz. ${ }^{30} \mathrm{E}$ a difusão de sua força propiciou a Igreja Católica outras ambições que não as religiosas. E a principal delas foi ratificar uma influência política sobre os Estados. E, assim, os líderes católicos perceberam que a busca pelo poder estava diretamente atrelada a uma demonstração de força, logo, um alinhar de interesses com o Estado seria vital para as novas pretensões eclesiásticas.

Sendo assim, tal como já tinha ocorrido no Império Romano, a religião começa a influenciar, via Igreja, nos poderes decisórios dos mandatários. E, com isso, não logrou muito tempo para a Igreja estar no centro das decisões políticas.

\footnotetext{
30 "A dificuldade dos cristãos com a pluralidade religiosa era relevante não apenas do ponto de vista teológico e interno à Igreja, mas também do lado social e político. No final da Antiguidade, o mundo era em grande parte pluralista. No gigantesco Império Romano, que ia da latitude de clima temperado-frio das ilhas britânicas e do centro da Europa até as zonas subtropicais do Alto Egito, de Gibraltar e do Monte Atlas no Ocidente até o Tigre e o Eufrates no Oriente, viviam inúmeros povos com suas respectivas línguas, culturas e tradições, em conjunto ou paralelamente. A religiosidade dessas comunidades ecumênicas (no sentido antigo) era marcada por uma multiplicidade de usos e cultos que se interpenetravam e misturavam permanentemente num clima bastante favorável ao sincretismo. Essa situação religiosa e por si só variegada parece ter-se alterado profundamente nos primórdios do período imperial. Inserida na família, no clã, na tribo e na cidade, a religião, que é uma questão de uso e tradição, passou a ser uma questão de livre-arbítrio. Em termos mercantis, surgiu uma concorrência entre grupos religiosos, desconhecida nos primórdios da Antiguidade, e o novo comportamento que levava a conflitos, principalmente àqueles condicionados pela religião. $\mathrm{O}$ cristianismo não chegou ao mundo como novo grupo religioso. Era uma oferta de sentido a mais no mercado das esperanças de salvação e promessas de cura. Contudo, do ponto de vista dos antigos, os cristãos agiam com seu ímpeto missionário e com enorme importância que, na falta de outras marcas de identidade, eles atribuíam com inabitual agressividade à confissão religiosa." (FÜRST, 2009, p. 102-103).
} 
O período histórico foi determinante para a influência da Igreja. ${ }^{31}$ A Igreja se aproveitou do período em que exercia forte influência, inclusive sobre o Estado, para acumular riquezas, conquistar territórios e ampliar seu domínio. $\mathrm{O}$ resultado direto foi o ganho de poder por parte da Igreja e, por conseguinte, amealhar não apenas novos fiéis para sua crença, como também, uma expansão territorial e o acúmulo de riquezas. E, assim, a religião se distanciava de sua principal função: a religiosa. Agora as preocupações eram nitidamente políticas em uma clara busca por poder.

O domínio da Igreja apenas aumentava, bem como seu patrimônio e sua riqueza. Na Europa, particularmente na França, ${ }^{32}$ se tornou comum os governantes serem coroados pelo Papa em uma clara demonstração de que o líder supremo do Estado estava submisso à Igreja. ${ }^{33}$ Evidentemente, os governantes não se mostraram felizes com essa expansão, todavia, contrariar o povo seria ainda pior, portanto, o período de dominação da Igreja perdurou por muitos séculos, mas começou a declinar exatamente com a própria Inquisição.

31 "A sociedade antiga era de índole religiosa. Do mesmo modo o Estado antigo e o Estado medieval, com suas crenças religiosas, o primeiro dominado pelo paganismo e o segundo pelo catolicismo. A Idade Média assistiu ao domínio pleno da Igreja Católica, inclusive atuando na esfera política, com a idéia da espada temporal e da espada espiritual, do poder sobre o mundo e sobre as almas. A religião católica teve predomínio intenso, impedindo a liberdade de crença e de culto, queimando nas fogueiras da Inquisição os hereges e os que discordavam de sua orientação. Basta lembrar o caso de Giordano Bruno, queimado em 1600 , torturado lentamente na fogueira durante duas horas, por defender idéias que foram inclusive adotadas por Einstein. Inúmeras figuras pagaram com a morte as suas crenças, como um crime de lesa-religião. Guerras surgiram entre as nações e massacres entre as pessoas da mesma pátria, como na noite de São Bartolomeu, na França, em 1572, quando os católicos trucidaram inúmeros huguenotes (protestantes)" (FERREIRA, 1998, p. 102).

32 "Na antiga França, a lei distinguia três ordens: o clero, a nobreza e o Terceiro Estado. Suas proporções numéricas são imprecisas: dos 23 milhões de habitantes que o reino podia conter, sem dúvida não havia mais de 100 mil sacerdotes, monges e freiras, e de $400 \mathrm{mil}$ nobres; todo o resto pertencia ao Terceiro Estado." (LEFEBVRE, 2011, p. 43).

33 "Ao longo de seus mais de trezentos anos de existência, naturalmente as estruturas da Inquisição evoluíram. Não devemos pensar que seu alcance administrativo tenha sido sempre universal e todo-poderoso, e, como vimos, na Espanha, o número de familiares diminuiu rapidamente no século XVII. No entanto, não há dúvidas de que, durante a maior parte de sua existência, a Inquisição atingiu quase todos os aspectos da vida da maior parte das pessoas. Por volta do século XVII, em Portugal, era considerada um Estado dentro do Estado e, indiscutivelmente, contava com a maior e mais poderosa burocracia do país" (GREEN, 2011, p. 277). 
O temor, as mortes sem sentido, a cultura que se perdeu devido à enormidade de livros que foram queimados abalaram a confiança cega do povo na Igreja. A figura do salvador se transformou na do inquisidor, uma nítida ameaça. E, com a queda da Inquisição, a própria Igreja começou a perder sua influência, foi, portanto, a oportunidade perfeita dos governantes reaverem seus territórios e aumentarem seus poderes. Em decorrência, a burguesia era a mais afetada com a expansão territorial da Igreja. Logo, ao perderem terras e, em concomitância, o Estado não ter o poder decisório pleno, ambos os lados perceberam que o cerne do problema era o mesmo: a influência da Igreja nas relações de poder. Assim, uma forma de se afastar a Igreja do poder era o mote fundamental a ser desenvolvido.

E foi a França, com o crescimento da burguesia, que determinou a mudança do poder, os eventos que antecederam a Revolução Francesa e a chegada ao poder por Napoleão Bonaparte acabaram por cindir a relação política que outrora existia entre Igreja e Estado. ${ }^{34}$ A própria coroação de Napoleão Bonaparte já demonstra isso, pois, através de pinturas existe a retratação do Papa corando Napoleão, em uma inferência clara ao domínio da Igreja sobre o Estado. Contudo, em outra tela temos Napoleão retirando a coroa das mãos do soberano religioso e se autocoroando, em uma separação entre Estado e Igreja.

Napoleão era um líder inteligente e astuto, portanto, excluir a Igreja, em um primeiro momento seria uma idiossincrasia, então, inicialmente houve uma aproximação, quando Bonaparte decretou uma trégua trazendo a Igreja para o abrigo do Estado, porém com uma série de restrições impostas pelo governante francês, o que culminou com uma ruptura definitiva. Entretanto, aos olhos do povo, Napo-

\footnotetext{
${ }^{34}$ Essa conjunção de fatores também foi igualmente importante para a derrocada da Inquisição como relata Toby Green (2011, p. 369): "Assim, podemos resumir da seguinte maneira os inimigos e os amigos da Inquisição em 1789: os inimigos era a liberdade, a igualdade e a interdependência; os amigos eram o status quo e a hierarquia. A instituição prosseguiu seriamente em suas tentativas de censura. A proibição de livros e a inspeção de bibliotecas tornaram-se sua função principal. Seus arquivos secretos cresciam com o grande número de casos documentados, à medida que cada vez mais livros eram publicados, promovendo o que ela considerava ideias ultrajantes. O grande número de livros proibidos naquela época assinala tanto o florescimento das edições quanto a incapacidade da Inquisição de conter seu fluxo. [...] Era impossível conter a libertinagem e o escárnio sobre a Inquisição e sobre tudo que ela prezava”.
} 
leão estava com a Igreja e foi esta que o abandonou, logo, o governo conseguiria, assim, consolidar a separação política definitiva com a Igreja.

O relato nos é trazido por E. Beau de Loménie, primeiro sobre a tentativa de reconciliação entre Bonaparte e a Igreja e depois, a cisão:

Bonaparte compreendeu que lhe era necessário achar um acôrdo com a Igreja, isto é, com o papado. Logo que subiu ao poder procurou entrar em negociações com Roma. Mas chocou-se imediatamente com muitas resistências. Os homens bem colocados, comprometidos por seu passado anticlerical, e com êles os eclesiásticos que tinham aderido à constituição civil do clero, temiam as represálias. As negociações foram longas e difíceis (LOMÉNIE, 1958, p. 116-117).

O acordo firmado ficou conhecido como a Concordata de Bonaparte e teve uma curta duração como nos relata em um segundo momento Loménie:

E outras complicações tinham surgido. Bonaparte não se contentara de negociar com a Igreja. No mesmo espírito de conciliação, êle procurara aliar a si, dando-lhes lugares em seus quadros administrativos, alguns dos membros da antiga nobreza que tinham voltado da emigração logo que a ordem interior fôra restabelecida. [...] $\mathrm{O}$ assunto cujas consequências iam ser as mais catastróficas foi o Bloqueio Continental, destinado em princípio a impelir a Inglaterra à ruína, fechando ao seu comércio todos os portos da Europa.

[...] Na Itália, o Papa recusou fechar seus portos aos inglêses. Napoleão ocupou então os Estados Pontificais. Daí surgiram irritações que, ajuntando-se às dificuldades já suscitadas pela aplicação da Concordata, levaram Napoleão a deportar o Papa Pio VII para Savana (LOMÉNIE, 1958, p. 118).

Era a ruptura entre a Igreja e o Estado. Esse movimento iniciado na França, com Napoleão Bonaparte, culminou com a cisão definitiva entre Estado e Igreja em 9 de setembro de 1905, quando a Terceira República promulgou a separação definitiva entre a Igreja e o Estado em forma de lei. Contudo, a ruptura não foi apenas a única consequência a ser enfrentada pela Igreja, pois, a maior punição aos líderes religiosos seria o laicismo. 


\section{A chegada do laicismo}

O Estado sempre buscou uma autonomia de decisões em relação à Religião, afinal dividir a soberania não é um interesse almejado pelos representantes do povo. Inúmeras foram as ações de governantes para afastar a influência da Igreja, ou melhor, da Religião de seus governos. Entretanto, a resistência religiosa também existiu e, por conseguinte, os estratagemas de manter o vínculo ativo.

Sobre o tema, Lucy Risso Moreira César (1982, p. 13) afirma:

Contra as pretensões dos Estados de se afastarem da influência do sacerdócio e da Igreja, os Papas Gregório XVI e Pio IX começam a combater as conseqüências do novo direito público, surgido das teorias protestantes, da Revolução Francesa, do século das luzes, do naturalismo e laicismo modernos.

E demonstra ainda a autora qual foi o contrarremédio adotado pela Igreja:

Neste sentido, inauguram as encíclicas, novo exercício do magistério que substitui o poder sobre a sociedade temporal. Trata-se de ensinamentos que ultrapassam o testemunho da fé, desenvolvendo as razões e conseqüências da doutrina, através da teologia, para esclarecer os problemas da Igreja e da sociedade (CÉSAR, 1982, p. 13).

Esse relato histórico nos mostra que a Igreja nunca deixou de tentar manter seu poder político independentemente da sua força religiosa, afinal, a expansão territorial e seu acúmulo de riquezas se deveram muito em parte ao estratagema de unir fé e política.

Entretanto, Marco Aurélio Cassamano (2006, p. 94 e ss) apresenta três acontecimentos fundamentais para a queda da Igreja e a ascensão do Estado: a) o Esta- 
do Moderno, b) a Reforma ${ }^{35}$ e o Protestantismo e c) a Secularização. E justifica o porquê desses três eventos:

O Estado Moderno representa a supremacia da força política, concentrada nas mãos do monarca absolutista, em detrimento da Igreja. A Reforma e o Protestantismo ocasionaram a quebra do monopólio religioso mantido até então pelo Catolicismo, provocando uma profunda mudança nos laços que prendiam a política à religião. Já a secularização é o processo pelo qual as pessoas, perdendo confiança num outro mundo ou no sobrenatural, abandonaram suas crenças religiosas, ou pelo qual a religião perdeu a sua influência na sociedade (CASSAMANO, 2006, p. 94 e ss).

Com a ruptura do Estado com a religião, a influência política da Igreja sobre o Estado cessou. Contudo, o receio dos detentores do poder em uma possível nova ascensão motivou uma resposta enérgica por parte dos governantes. Como se fora um recado direto sobre quem, agora, retinha o poder. Destarte, na França, com a ruptura em 1905 se inaugurou um período de completa intolerância à Igreja, foi o que se denominou de Laicismo.

Laicismo pode ser traduzido como a completa ignorância da presença da Igreja e, pior, da própria Religião, como em um ato de censura, especialmente a França, a partir da ruptura com a Igreja em 1905, instaurou a proibição de manifestação religiosa, atos de fé e, por que não dizer da própria manifestação da Igreja.

A Carta do Papa João Paulo II a D. Jean-Pierre Ricard, Arcebispo de Bordéus e Presidente da Conferência Episcopal Francesa possuem importante dados acerca da separação do Estado e da Igreja e a relação de tais fatos com o laicismo:

\footnotetext{
${ }^{35}$ Miguel Chaia (2005, p. 39): A tolerância contra a intolerância religiosa desloca-se, de forma laica, para a ordem política. Calvino, mesmo reconhecendo que o governo secular e o reino interno e espiritual de Cristo são diferentes, tornou-se "[...] partidário de uma ordem política que toma a seu cargo impedir que a verdadeira religião, a qual está contida na lei de Deus, seja manchada e violada com impunidade pela heresia pública e ofensiva. A lei moral, com duplo sentido, quais sejam reverenciar a Deus e amar nosso próximo, fornece a argamassa para a organização político-cristã que é engendrada a partir da Reforma e afeta a ordem civil, as leis e a organização do povo".
} 
Em 1905, a lei de separação da Igreja e do Estado, que denunciava a Concordata de 1804, foi um acontecimento doloroso e traumatizante para a Igreja na França. Ela regulava o modo de viver em França o princípio do laicismo e, neste âmbito, ela mantinha unicamente a liberdade de culto, relegando ao mesmo tempo a fé religiosa para a esfera privada e não reconhecendo à vida religiosa e à Instituição eclesial um lugar no seio da sociedade. Desta forma, a vida religiosa do homem era considerada unicamente como um simples sentimento pessoal, não reconhecendo assim a natureza profunda do homem, ser ao mesmo tempo pessoal e social em todas as suas dimensões, incluindo a dimensão espiritual. (PAULO II, 2005)

Sendo assim, podemos concluir que o laicismo é a supressão da religião da realidade estatal, a ponto de a mesma não ser considerada sequer como um elemento de fé, pertencente a todos os seres humanos, logo, presente na sociedade. As pessoas poderiam cultuar seus deuses, exercer seus votos religiosos, desde, que não turbassem a ordem social, ou seja, é o mesmo que dizer que a religião somente estava autorizada no interior dos lares das pessoas.

A intenção foi realmente cindir qualquer tipo de influência da Igreja com o Estado, como consequência direta à ruptura promovida pela França, através dos atos relatados anteriormente por nós e que culminaram na definitiva ruptura em 1905.

E prossegue João Paulo II a falar sobre o laicismo na mesma carta:

O princípio do laicismo, ao qual o vosso País está muito ligado, se for bem entendido, faz também parte da Doutrina social da Igreja. Ele recorda a necessidade de uma justa separação dos poderes (cf. Compêndio da Doutrina Social da Igreja, nn. 571-572), que faz eco ao convite feito por Cristo aos discípulos: "Dai, pois, a César o que é de César e a Deus o que é de Deus" (Lc 20,25). Por seu lado, a nãoconfessionalidade do Estado, que é uma não-ingerência do poder civil na vida da Igreja e das diferentes religiões, assim como na esfera do espiritual, permite que todos os componentes da sociedade trabalhem juntos ao serviço de todos e da comunidade nacional. De igual modo, como recorda o Concílio Vaticano II, a Igreja não tem por vocação a gestão do que é temporal, pois, "em razão da sua missão e competência, não pode confundir-se de modo algum com a comunidade política nem está ligada a nenhum sistema 
político" (Constituição Gaudium et spes, n. 76; cf. n. 42). Mas, ao mesmo tempo, é fundamental que todos trabalhem pelo interesse geral e pelo bem comum. É neste sentido que o Concílio diz: "No terreno que lhe é próprio, a comunidade política e a Igreja, são independentes e autónomas. Mas ambas, embora a títulos diferentes, estão ao serviço da vocação pessoal e social dos mesmos homens. Exercerão tanto mais eficazmente este serviço para o bem de todos quanto mais cultivarem entre si uma sã cooperação". (PAULO II, 2005).

A manifestação papal apenas demonstra que a Igreja nunca deixou de lutar contra esse "banimento" por parte do Estado. O que o Papa insiste em dizer é que não se pode suprimir a fé das pessoas como forma de ratificar a soberania política de um Estado, uma coisa não se confunde com outra, logo, a solução apresentada pelo Pontífice é a liberação da religião sem nenhum tipo de vínculo com o Estado, o que viria a se denominar laicidade. ${ }^{36}$

\footnotetext{
${ }^{36}$ Parte final da Carta de João Paulo II, como forma de ratificar a laicidade: "Reconhecer a dimensão religiosa das pessoas e dos componentes da sociedade francesa, significa querer associar esta dimensão às outras dimensões da vida nacional, para que contribua com o seu dinamismo para a edificação social e para que as religiões não se refugiem num sectarismo que poderia representar um perigo para o próprio Estado. A sociedade deve poder admitir que as pessoas, no respeito do próximo e das leis da República, possam manifestar a sua pertença religiosa. Em caso contrário, corre-se sempre o risco de um fechamento de identidade e sectário, e do incremento da intolerância, que impede a convivência e a concórdia no seio da Nação. Devido à vossa missão, estais chamados a intervir regularmente nos debates públicos sobre as grandes questões da sociedade. De igual modo, em nome da sua fé, os cristãos, pessoalmente ou em associações, devem poder tomar a palavra publicamente para expressarem as suas opiniões e manifestar as suas convicções, contribuindo assim para os debates democráticos, interpelando o Estado e os seus concidadãos sobre as responsabilidades de homens e mulheres, principalmente no campo dos direitos fundamentais da pessoa humana e do respeito da sua dignidade, do progresso da humanidade que não pode ser obtido a qualquer preço, da justiça e da igualdade, assim como da proteção do planeta, são âmbitos que dizem respeito ao futuro do homem e da humanidade, e à responsabilidade de cada geração. Eis por que a laicidade, longe de ser o lugar de um confronto, é verdadeiramente o espaço para um diálogo construtivo, no espírito dos valores de liberdade, igualdade e fraternidade, que são justamente muito queridos ao povo da França”.
} 


\section{Os Direitos Humanos e a ruptura do laicismo}

Enquanto nos países ocidentais a Igreja observava sua dominação e sua influência serem nitidamente reduzidas, o mesmo não se pode dizer dos países do mundo árabe, aos quais, em sua esmagadora maioria, não apenas adotam o islamismo como religião oficial, como esta tem uma influência muito presente em termos políticos.

Ao invés de existir e de se edificar uma aproximação entre as religiões, o que se viu ao longo dos séculos foi um profundo distanciamento, com caminhos a serem trilhados em movimentos distintos. Enquanto as religiões cristãs buscavam ocupar novamente o centro decisório com uma influência político-religiosa, os líderes islâmicos se preocupavam em edificar o Estado de acordo com os seus interesses e, assim, criar um ideal político religioso.

A mudança da realidade religiosa ocidental ocorreu com dois eventos que modificaram sobremaneira o cenário político e geográfico do mundo: as duas Guerras Mundiais. Mais importante do que discutir o boicote aos ideais da Igreja, tivemos uma profunda mudança acerca do conceito da vida humana, pois a banalização e o descarte motivados pelas milhares de vidas dizimadas como espólio de Guerra, agora, eram a agenda do dia. Afinal, com o término da Segunda Guerra Mundial, que perdurou de 1939 a 1945, foi deixado um espólio estimado entre 40 a 52 milhões de pessoas mortas em decorrência dos conflitos.

Não existe afronta maior contra a vida de um ser humano do que uma guerra? O que diriam as autoridades e os defensores dos direitos humanos por conta da ação humana mais de quarenta milhões de vidas deixaram de existir? Ademais, somente as mortes já seriam uma justificativa minimamente razoável para uma mudança de paradigma, porém, a Segunda Guerra Mundial conteve requintes específicos de crueldade que afrontam a dignidade de qualquer ser humano. $\mathrm{O}$ holocausto produziu cenas terríveis protagonizadas em campos de concentração, 
em especial Auschwitz ${ }^{37}$ e Bikernau com esterilização em massa, experimentos em seres vivos, em corpos, mortes em câmaras de gás, perseguições e agressões que culminaram com mortes por conta de orientação sexual, raça e religião.

A história nos mostra que os direitos humanos sempre foram impulsionados por acontecimentos históricos, isto é, firmaram-se ao longo do tempo como uma resposta aos fatos sociais em um determinado espaço-tempo, assim, receberam a classificação de direitos humanos de primeira, segunda e terceira geração.

Para nosso estudo será importante situar o surgimento dos direitos humanos, portanto, iremos apresentar o surgimento histórico dos direitos humanos, sem deixar de mencionar as influências históricas, contudo, não adentraremos na questão da classificação dos direitos humanos, pois, iremos por um caminho distinto.

Nossa missão será apresentar como eram os direitos humanos pós-Independência Americana e Revolução Francesa e como ficaram após as duas grandes guerras mundiais, as mudanças de paradigma e o novo caminho a ser defendido. Toda a nossa atenção sobre os Direitos Humanos estará centrada na questão religiosa, tanto na permissibilidade como no combate aos abusos.

\footnotetext{
${ }^{37}$ Hannah Arendt fornece o relato histórico acerca da funcionalidade de Auschwitz: "Lendo as atas do julgamento, deve-se ter sempre em mente que Auschwitz fora estabelecido para massacres administrativos que deviam ser executados segundo as regras e regulamentos mais rigorosos. Essas regras e regulamentos tinham sido estipulados pelos assassinos burocratas, e eles pareciam excluir - provavelmente tinham a intenção de excluir - toda iniciativa individual, quer para melhorar a situação, quer para piorá-la. O extermínio de milhões foi planejado para funcionar como uma máquina: os prisioneiros chegando de toda a Europa; as seleções na rampa, e as seleções subseqüentes entre aqueles que tinham sido robustos na chegada; a divisão em categorias (todos os idosos, crianças e mães com filhos deviam ser gaseados imediatamente); os experimentos humanos; o sistema dos "prisioneiros de confiança", os capôs e os comandos de prisioneiros que manejavam as instalações de extermínio e detinham posições privilegiadas. Tudo parecia previsto e assim previsível - dia após dia, mês após mês, ano após ano. E, ainda assim, o que resultou dos cálculos burocráticos foi o exato oposto da previsibilidade. Foi uma completa arbitrariedade" (ARENDT, 2004, p. 319-320).
} 


\subsection{Os Direitos Humanos - evolução histórica}

A doutrina determina que a primeira geração de direitos humanos tenha seu início com a Independência Americana e a Revolução Francesa. ${ }^{38}$ Contudo, é inegável a contribuição de alguns outros atos anteriores. Foi assim com a Magna Carta Inglesa em 1215, e, principalmente, com os atos impulsionados nos séculos XVI e XVII, por advento do movimento conhecido como iluminismo, quando uma série de atos foi profícua para o desenvolvimento dos direitos humanos fundamentais por meio do habeas corpus act, de 1679; o Bill of Rights em 1689. No entanto, é necessário compreender o contexto histórico para concordar com a doutrina. ${ }^{39}$

${ }^{38}$ Nilo Odalia (2010, p. 159): “Compreender-se a Revolução Francesa como fundadora dos direitos civis impõe que não nos esqueçamos de que o século XVIII é conhecido como o século do Iluminismo e da Ilustração, por ser o século de Voltaire e Montesquieu, de Kant e Holbach, de Diderot e D’Alembert, de Goethe e Rousseau, de Mozart e Beethoven. Nele se deu, também, a tentativa de transformar as ciências da natureza em ciências da razão e da experimentação." Somado ao relato de Nilo Odalia, temos de considerar os séculos de opressão da Igreja Católica em decorrência da Inquisição, a dominação do Clero e da Nobreza sobre a esmagadora maioria da população francesa denominada de Terceiro Estado. No entanto, o Terceiro Estado, ao qual se situava a burguesia, era explorado e perdia riquezas e territórios para o Clero, especialmente, e para a nobreza. Em toda essa conjuntura histórica, era de se esperar que a Revolução fosse apenas uma questão de tempo. E ainda, com a influência dos ideais propostos pela abertura de Napoleão Bonaparte o avanço em defesa das liberdades e a cisão com a tirania e com a submissão eram inevitáveis. E o marco dessa Revolução foi a consequência direta produzida ao longo do globo, pois, se não foi o embrião dos direitos fundamentais, foi, sem dúvida, a sua mola propulsora.

${ }^{39} \mathrm{Na}$ verdade, Norberto Bobbio elucida a importância dos movimentos anteriores à Revolução Francesa e explica os motivos de não serem considerados como marcos para os direitos humanos: "A relação tradicional entre direitos dos governantes e obrigações dos súditos é invertida completamente. Até mesmo nas chamadas cartas de direitos que precederam as de 1776 na América e a de 1789 na França, desde a Magna Charta até o Bill of Rights de 1689, os direitos ou as liberdades não eram concedidos ou concertados, devendo parecer - mesmo que fossem resultado de um pacto entre súditos e soberano - como um ato unilateral deste último. O que equivale dizer que, sem a concessão do soberano, $\mathrm{o}$ súdito jamais teria tido qualquer direito. Não é diferente o que ocorrer; a no século XIX: quando surgem as monarquias constitucionais, afirma-se que as Constituições foram octroyées pelos soberanos. O fato de que essas Constituições fossem a consequência de um conflito entre rei e súditos, concluído com um pacto, não devia cancelar a imagem sacralizada do poder, para a qual os cidadãos obtêm é sempre o resultado de uma graciosa concessão do príncipe. As Declarações de Direito estavam destinadas a inverter essa imagem. E, com efeito, pouco a pouco lograram invertê-la. Hoje, o próprio conceito de democracia é inseparável do conceito de direitos do homem" (BOBBIO, 2004, p. 114). 
Afinal, se a concessão de um direito dependia de um soberano, então o direito não era universal e a disposição do homem, logo, ao ser atrelada à vontade de outrem se tornava restrito, realidade essa, que realmente, somente se modificou com as Declarações Americana de 1776 e a Francesa de 1789. Todavia, a quebra de paradigma se iniciou com o Iluminismo, pois esse movimento foi o responsável por impulsionar novamente os ideários dos direitos humanos, que resultaram nos processos de conflitos na França e nos Estados Unidos, que culminaram com a Revolução Francesa e a Independência Norte-americana, respectivamente, e que determinaram o surgimento da primeira geração dos Direitos Humanos. ${ }^{40}$

Todos esses atos foram importantes para desenvolver o conceito de liberdade, fraternidade e igualdade entre todos os homens. Contudo, os conflitos e, especialmente as mortes, impulsionaram uma necessidade de buscar a valoração do próprio homem. E a Primeira Guerra Mundial que ocorreu entre 1914 e 1918, com um saldo negativo de 9 milhões de mortos, acelerou ainda mais o processo.

No entanto, como que as Nações se organizaram para discutir e desenvolver um contrarremédio às agruras trazidas pelas guerras? A resposta a essa indagação, a nosso ver, representou a evolução concreta dos direitos humanos para a defesa do cidadão.

\subsection{Os Direitos Humanos pós Ia e IIa Guerras Mundiais}

Os Direitos Humanos conheceram uma nova fase com o final da Segunda Guerra Mundial, em um movimento que se iniciou com as guerras francesas e sua Declaração dos Direitos do Homem em 1789. O marco histórico é a presença na Declaração Francesa de 1789 do artigo 2: "A finalidade de toda associação política é a preservação dos direitos naturais e imprescritíveis do homem. Esses direitos são a liberdade, a prosperidade, a segurança e a resistência à opressão".

${ }^{40}$ Fábio Konder Comparato afirma: "O artigo I da Declaração que "o bom povo da Virgínia" tornou pública, em 16 de junho de 1776, constitui o registro de nascimento dos direitos humanos na História" (COMPARATO, 2003, p. 49). 
Com o término das guerras e a perda inestimável de milhões de vidas, o primeiro grande ato em busca da defesa dos direitos humanos foi a criação, em 26 de junho de 1945, em São Francisco, de um órgão que iria representar os cinquenta e um países signatários e proteger os cidadãos, suas relações, liberdades, etc. Nascia assim a Organização das Nações Unidas (ONU). Apenas três anos após a sua criação, em 1948, a ONU aprovou a Declaração Universal de Direitos do Homem, ${ }^{41}$ que, notadamente, foi influenciada pela Declaração de 1789, mas lapidada pelas agruras dos acontecimentos históricos já referidos.

O preâmbulo já possui os elementos norteadores do que viriam a se traduzir em um novo conceito de Direitos humanos ao justificar os anseios sociais das pessoas comuns. ${ }^{42}$ José Lindgren Alves (1997, p. 27) já apontava as semelhanças:

Seus postulados fundamentais, que remontam à Revolução Francesa, são a liberdade, a igualdade e a fraternidade, expressos na formulação do Artigo $1^{\circ}$ de que "todas as pessoas nascem livres e iguais em dignidade e direitos", devendo agir reciprocamente "com espírito de fraternidade". Desses postulados decorre o princípio da não discriminação por motivo de raça, cor sexo, língua, religião, opiniões, origem nacional ou social, riqueza, nascimento ou qualquer outra condição, inclusive a situação política, jurídica ou nível de autonomia do território a que pertençam às pessoas explicitado no Artigo $2^{\circ}$.

\footnotetext{
${ }^{41}$ Norberto Bobbio (2004, p. 47) afirma que: "A Declaração Universal dos Direitos do Homem pode ser acolhida como a maior prova histórica até hoje dada do consensus omnium gentium sobre um determinado sistema de valores. Os velhos jusnaturalistas desconfiavam - e não estavam inteiramente errados - do consenso geral como fundamento do direito, já que esse consenso era difícil de comprovar. Seria necessário buscar sua expressão documental através da inquieta e obscura história das nações, como tentaria fazê-lo Giambattista Vico. Mas agora esse documento existe: foi aprovado por 48 Estados, em 10 de dezembro de 1948, na Assembléia Geral das Nações Unidas; e, a partir de então, foi acolhido como inspiração e orientação no processo de crescimento de toda a comunidade internacional no sentido de uma comunidade não só de Estados, mas de indivíduos livres e iguais".

${ }^{42}$ Considerando que o reconhecimento da dignidade inerente a todos os membros da família humana e de seus direitos iguais e inalienáveis é o fundamento da liberdade, justiça, e da paz no mundo. Considerando que o desprezo a o desrespeito pelos direitos humanos resultou em atos bárbaros que ultrajaram a consciência da Humanidade e que o advento de um mundo no qual os seres humanos gozem de liberdade de expressão e de crença e da liberdade de viverem a salvo do temor e da necessidade, foi proclamado como a mais alta aspiração do homem comum. (Duas primeiras partes do preâmbulo) (ALVES, 1997, p. 49).
} 
Com a Declaração Universal dos Direitos do Homem, ${ }^{43}$ de 1948, o homem, ou melhor, a dignidade da pessoa humana, passou a ser a principal preocupação, o alvo máximo de proteção e também, um novo marco histórico fundamental; pela primeira vez fora criado um documento universalmente aceito pela maioria das pessoas, por meio da ratificação de seus governos, um conjunto de regramentos e comportamentos sociais criados pelo próprio homem, sem que houvesse algum tipo de envolvimento da Igreja e que abrangesse a todos e não a determinados grupos, como no caso da religião e das Igrejas. ${ }^{44}$

Sempre a humanidade reagiu positivamente após um grande mal causado pelo próprio homem, foi assim com a Convenção de Viena, após o final da I Guerra Mundial e foi assim com a criação de um organismo transnacional, independente responsável por regular as relações sociais e humanitárias entre os seus EstadosMembros, papel esse que passou a ser desenvolvido pela ONU a partir de 1945.

Após a Declaração Universal dos Direitos do Homem, de 1948, uma série de atos, resoluções e medidas foram desenvolvidas para proteger o direito das minorias e, acima disso, garantir a igualdade de direitos, independentemente da orientação política, sexual ou religiosa.

${ }^{43}$ Norberto Bobbio tinha dúvidas se a humanidade tinha consciência da grandeza do que a Declaração Universal dos Direitos do Homem representava para a própria história: "Não sei se tem consciência de até que ponto a Declaração Universal representa um fato novo na história, na medida em que, pela primeira vez, um sistema de princípios fundamentais da conduta humana foi livre e expressamente aceito, através de seus respectivos governos, pela maioria dos homens que vivem na Terra" (BOBBIO, 2004, p. 47).

44 "Com essa declaração, um sistema de valores é - pela primeira vez na história - universal, não em princípio, mas de fato, na medida em que o consenso sobre a validade e sua capacidade para reger os destinos da comunidade futura de todos os homens foi explicitamente declarado. (Os valores de que foram portadoras as religiões e as Igrejas, até mesmo a mais universal das religiões, a cristã envolveu de fato, isto é, historicamente, até hoje, apenas uma parte da humanidade.) Somente depois da Declaração Universal é que podemos ter a certeza histórica de que a humanidade - toda a humanidade - partilha alguns valores comuns; e podemos, finalmente, crer na universalidade dos valores, no único sentido em que tal crença é historicamente legítima, ou seja, no sentido em que universal significa não algo dado objetivamente, mas algo subjetivamente acolhido pelo universo dos homens" (BOBBIO, 2004, p. 48). 
Assim, com a busca por um sistema de Direitos Humanos calcado na liberdade religiosa, não mais fazia sentido o laicismo e, paulatinamente, este foi sendo transmutado pela laicidade, ou seja, a não interferência do Estado em questões religiosas e vice-versa.

Trata-se, portanto, de um novo cenário para o Estado e para a Igreja: a segunda tem total liberdade na sociedade, desde que não atue politicamente ou, tampouco, influa no poder decisório do Estado.

É a acepção da tolerância e da liberdade religiosa, a qual a própria Igreja teve papel fundamental com o Pacem in Terris, como demonstra Claude Geffré (1993, p. 50):

\begin{abstract}
Tomemos o exemplo da França onde fizemos a aprendizagem, de parte a parte, tanto da parte do Estado como da parte da Igreja, do que significa uma verdadeira toler6ancia, após a herança difícil da Revolução vivida pelos católicos. É certo que o Vaticano II operou uma reviravolta notável, ou seja, pela primeira vez a Igreja - já na pessoa de João XXIII no momento da Pacem in Terris em 1963, e depois no concílio do Vaticano II em sua Declaração sobre a liberdade religiosa - aceitou o princípio de uma sociedade leiga, de uma sociedade pluralista, de uma sociedade que tem sua legitimidade, mesmo se essa sociedade não possui um fundamento imediatamente religioso.
\end{abstract}

Já o Estado não minora ou interfere nas práticas religiosas da Igreja e professa uma liberdade de crença e culto, ou seja, o surgimento de um Estado tolerante, ou laico. Assim sendo, o mote fundamental passou a ser a defesa de uma liberdade religiosa, da possibilidade de se cultuar o seu Deus, de se fazer o proselitismo religioso, desde que nenhum desses atos interfira negativamente na liberdade dos demais.

E a questão da tolerância foi englobada como um dos principais meios de proteção da Constituição dos Países. E, na ausência de um tipo normativo 
especifico, os Estados têm aderido a uma série de instrumentos internacionais desenvolvidos para assegurar a tolerância, por intermédio de Tratados, Convenções, Pactos etc. ${ }^{45}$

\subsection{A tolerância religiosa}

Jacques Le Goff (2000, p. 38) afirma que o conceito de tolerância surgiu no século XVI:

${ }^{45}$ Declaração Francesa de Direitos do Homem, através do seu artigo 10; A Carta das Nações Unidas, de 26 de junho de 1945; O preâmbulo da Declaração Universal dos Direitos do Homem, bem como o seu artigo $2^{\circ}$; A Convenção Europeia dos Direitos do Homem, firmada em Roma, em 4 de novembro de 1950, através dos artigos 14, 18 e 26; Declaração sobre a Prevenção e Punição do Crime de Genocídio; A Carta Encíclica PACEM IN TERRIS editada pelo Vaticano, em 11 de abril de 1963; Na sequência, o Vaticano emitiu, em 1965, a Declaração DIGNITATIS HUMANAE; O artigo $4^{\circ}$ da Convenção Relativa ao Estatuto dos Refugiados; No mesmo sentido, a proteção a prática religiosa em relação aos apátridas, conforme os artigos $3^{\circ}$ e $4^{\circ}$ da Convenção relativa aos Apátridas; Em 1965, um novo marco histórico com a criação da Convenção Internacional sobre a Eliminação de Todas as Formas de Discriminação Racial; Na mesma esteira, temos o Pacto Internacional sobre Direitos Civis e Políticos, de 1966; Ainda em 1966, tivemos o Pacto Internacional Sobre Direitos Econômicos, Sociais e Culturais e a questão da liberdade religiosa está presente no artigo 13; Em 1979, a Convenção sobre a Eliminação de Todas as Formas de Discriminação Contra as Mulheres; Em 1980, o então Papa João Paulo II emitiu uma mensagem aos países signatários do Ato final de Helsinque; E, em 1981, a ONU emitiu a mais importante Declaração sobre o assunto religião: A Declaração sobre a Eliminação de Todas as Formas de Intolerância e Discriminação Baseadas em Religião ou Crença; Em $1^{\circ}$ de janeiro de 1988, o Papa João Paulo II emite uma mensagem por ocasião da celebração do XXI Dia Mundial da Paz; Em 1989, a ONU edita a Convenção Sobre os Direitos da Criança e sobre liberdade religiosa; é importante destacar o artigo 14; Em 1992 tivemos a importante Declaração Sobre os Direitos das Pessoas Pertencentes a Minorias Nacionais ou Étnicas, Religiosas e Linguísticas; Em 1994, foi editado o Conselho da Liga dos Estados Árabes, isto é, a Carta Árabe de Direitos Humanos; Em 1993 um novo passo para a ratificação dos direitos humanos, com a Declaração e Programa de Ação de Viena através da Conferência Mundial sobre Direitos Humanos, realizada em Viena entre os dias 14 e 25 de junho; em 2005, a Declaração Universal da Laicidade no século XXI; E, recentemente, a União Europeia, em 30 de março de 2010, criou seu próprio regramento de direitos humanos através da Carta dos Direitos Fundamentais da União Europeia. A liberdade religiosa também foi mencionada no capítulo Liberdade de Pensamento, de Consciência e de Religião. Além de uma menção expressa ao respeito à diversidade religiosa no artigo 22 (Cf. GEFFRÉ, 1993, p. 50). 
A noção de tolerância (e, correlativamente, a de intolerância) surge no século XVI. Uma de suas primeiras utilizações públicas é encontrada no Edito de Tolerância (1562), que concede liberdade de culto aos protestantes. A partir do final do século XVII, ela é amplamente utilizada (assim como a de intolerância). A idéia de que a tolerância não é natural, mas exige um certo esforço para ser aceita, uma disciplina, perdura até nossos dias. A tolerância é uma construção, uma conquista.

A Santa Inquisição ensinou o que deve ser tolerância e como que a violência e a manipulação política podem ser usadas a fim de manter um ideal forçosamente (BIGNOTTO, 2004, p. 73). ${ }^{46}$ Segundo Jean Baubérot (1993, p. 79):

Se o problema da tolerância é secular, ele se coloca de uma maneira nova, no Ocidente cristão, a partir do século XVI. Com efeito, se produz - naquele momento - um fato novo: uma "heresia" não é historicamente vencida. Ao contrário, triunfa em vários territórios. Doravante a unidade religiosa é rompida. Ora, essa heresia reivindicou a liberdade de consciência. Convocado à dieta de Worms, em abril de 1521, Martinho Lutero, excomungado no ano precedente, éintimado a retratar-se. Ele declara: 'Não deposito fé exclusivamente no papa e nos concílios [...]. Atenho-me aos textos da Escritura que citei e minha consciência prende-se às palavras de Deus. Não posso nem quero retratar-me de nada, pois não é certo nem honesto agir contra sua própria consciência. $\mathrm{O}$ representante do bispo de Trier republica então: 'Abandona tua consciência, irmão Martinho. A única coisa sem perigo consiste em submeter-se à autoridade estabelecida?.

${ }^{46}$ Para Newton Bignotto (2004, p. 73), "A diferença religiosa não é aqui objeto de tolerância, mas de perseguição, pois ameaça não mais as crenças religiosas da maioria da população, mas seu próprio caminhar em direção ao esclarecimento". Essa importante passagem de Newton Bignotto pode ser aplicada à exasperação da Inquisição, com a aniquilação da cultura, dos livros e dos conhecimentos de outros povos, então considerados hereges pela Igreja. Quando, em verdade, tais atos denotavam mais do que a intolerância que, por si só, já seria condenável, porém, igualmente tratava da forma atroz de manter uma reprimenda com o uso indiscriminado da força de que a Religião cristã era a melhor de todas e que o simples contato com as demais ou com elementos alheios ao catolicismo já colocavam o individuo como passível de ser considerado um herege. Logo, tais atos, representam o elevado temor da Igreja Católica em perder o seu domínio pelo uso da força e da violência, uma perda que se tornou inevitável, mais tarde, com a propagação da liberdade, da igualdade e da busca pela abertura e do fim do terror. Os movimentos terroristas com fins políticos que usam do medo para atingir seus objetivos precípuos têm em sua inspiração muito dos negativos ensinamentos do período da Inquisição. 
No entanto, o impacto maior sobre o que vem a ser tolerância e a sua relação com os Estados ocorreu no final do Século XVIII. A mudança do paradigma, ocasionado pela Revolução Francesa e que culminou com o estabelecimento dos Direitos Humanos, afirmou como mote fundamental a questão da liberdade religiosa. E mais do que isso: para a sua concretude seria vital o estabelecimento da tolerância.

Com isso, não há que se falar em Direitos Humanos ou em defesa da liberdade religiosa sem o respeito à tolerância. Contudo, é mais fácil ficar no plano teórico do que no plano prático, pois, no mais das vezes, os próprios Estados que se dizem laicos e defendem a laicidade praticam intolerâncias contra as minorias religiosas.

Para superar o conflito trazido pelo Estado e sua própria intolerância, é necessário analisar a influência política sobre o tema. E, assim, Norberto Bobbio (2004, p. 207) demonstra a influência política nas questões relacionadas à tolerância: ${ }^{47}$

A idéia de tolerância nasceu e se desenvolveu no terreno das controvérsias religiosas. Seus grandes defensores, de Locke a Voltaire, combateram todas as formas de intolerância que ensangüentaram a Europa durante séculos, depois da ruptura do universalismo religioso por obra das Igrejas reformadoras e das seitas heréticas. Do terreno das controvérsias religiosas a ideais de tolerância passou pouco a pouco para o terreno das controvérsias políticas, ou seja, do contraste entre aquelas formas de religião moderna que são as ideologias. O reconhecimento da liberdade religiosa deu origem aos Estados não confessionais; o reconhecimento da liberdade política, aos Estados democráticos.

${ }^{47}$ Em outra obra, Bobbio (2002, p. 149) também se posiciona: “O motivo pelo qual me ocupo das razões da tolerância no primeiro sentido é que o problema histórico da tolerância, tal como foi posto na Europa durante o período das guerras de religião, e sucessivamente pelos movimentos heréticos e depois pelos filósofos, como Locke e Voltaire, o problema tratado nas histórias da tolerância (como a mais famosa, a de Joseph Lecler, em dois volumes, 1954), é o problema relativo exclusivamente à possibilidade de convivência de confissões religiosas diversas, problema nascido na época em que ocorre a ruptura do universo religioso cristão". 
De tal sorte que a missão primordial dos Direitos Humanos é estabelecer o conceito de tolerância e como esse se processa no âmbito externo e interno dos Estados para, em um momento posterior, tratar da questão da tolerância no âmbito individual.

Norberto Bobbio (2002, p. 152) se preocupa com os limites da tolerância:

O problema é que habitualmente posto nestes termos: a tolerância tem limites? E, se tem limites, onde devem ser postas as fronteiras? Como não existem sociedades absolutamente intolerantes, também não existem sociedades absolutamente tolerantes: ou se fica no Estado absoluto do Grande Irmão, ou se fica na sociedade igualmente imaginária na qual vale a máxima "Se não há Deus, tudo é permitido". Entre os dois extremos, ambos puramente fantásticos, existem muitos graus intermediários.

O objetivo primeiro da tolerância é a coexistência pacifica entre os povos e nações com as histórias, culturas, tradições e, principalmente, religiões dos demais, sem qualquer tipo de interferência, restrição, desrespeito ou violência. ${ }^{48}$

Lemos em Wolf Lepenies (2000, p. 117):

Por que é tão difícil a luta pela tolerância? Uma possível resposta - preferiria chamá-la de a resposta resignada do pensamento conservador - é que a natureza humana não pode mudar, e uma de suas "virtudes"é, de fato, a intolerância, ou seja, o desejo de colocar claramente prioridades e preferências, e destruir tudo aquilo que parece afastar-se delas ou opor-se a elas. Desse ponto de

\footnotetext{
48 “Tolerância: 'paciência através da qual se sofre ou dissimula alguma coisa', diz Furetière. A desaprovação não acarreta a exclusão nem a perseguição. Mas a tolerância não é neutralidade; é uma posição que só se pode manter a condição de haver definido seus limites, em função do intolerável. Qual o lugar do sujeito que julga o intolerável? Acaso ele se considera na posição da verdade, do universal? Ou reconhece sua própria posição como singular? Consegue ele instalar-se numa espécie de desvio, deixando passar como supérfluos os desafios de uma polêmica? Seja qual for esse lugar, ele determina como que um recurso de direitos para fundar ou condenar a tolerância. Mas, para interrogar os formulários de exclusão e os dispositivos de integração, pode-se substituir a questão do fundamento da tolerância por uma análise do intolerável, pensado na formação das sensibilidades pelas instituições" (MARKOVITS, 1993, p. 114).
} 
vista, o único meio de atingir a tolerância, se é que pode ser atingida, é pela prática de uma política regressiva, uma luta contínua contra o homem que, por natureza, é "puro", isto é, intolerante.

Tolerância, ${ }^{49}$ assim, é o exercício da plena liberdade, seja cultural, religiosa, política, de pensamento, sem que para isso seja preciso agredir o próximo ou muito menos impor uma posição aos demais. ${ }^{50}$

${ }^{49}$ Em 16 de novembro de 1995, foi aprovada na 28ª reunião da Conferência Geral entre os Estados Membros da Organização das Nações Unidas, para a Educação, a Ciência e a Cultura a Declaração de Princípios sobre Tolerância. E no art. $1^{\circ}$ estabelece: A tolerância é o respeito, a aceitação e o apreço da riqueza e da diversidade das culturas de nosso mundo, de nossos modos de expressão e de nossas maneiras de exprimir nossa qualidade de seres humanos. É fomentada pelo conhecimento, abertura de espírito, a comunicação e a liberdade de pensamento, de consciência e de crença. A tolerância é harmonia na diferença. Não só é um dever de ordem ética; é igualmente uma necessidade política e de justiça. A tolerância é uma virtude que torna a paz possível e contribui para substituir uma cultura de guerra por uma cultura de paz. 1.2. A tolerância não é concessão, condescendência, indulgência. A tolerância é, antes de tudo, uma atitude ativa, fundada no reconhecimento dos direitos universais da pessoa humana e das liberdades fundamentais do outro. Em nenhum caso a tolerância poderia ser invocada para justificar lesões a esses valores fundamentais. A tolerância deve ser praticada pelos indivíduos, pelos grupos e pelos Estados. 1.3. A tolerância é o sustentáculo dos direitos humanos, do pluralismo (inclusive o pluralismo cultural), da democracia e do Estado de Direito. Implica a rejeição do dogmatismo e do absolutismo e fortalece as normas enunciadas nos instrumentos internacionais relativos aos direitos humanos. 1.4. Em consonância ao respeito dos direitos humanos, praticar a tolerância não significa tolerar a injustiça social, nem renunciar às próprias convicções, nem fazer concessões a respeito. A prática da tolerância significa que toda pessoa tem a livre escolha de suas convicções e aceita que o outro desfrute da mesma liberdade. Significa aceitar o fato de que os seres humanos, que se caracterizam naturalmente pela diversidade de seu aspecto físico, de sua situação, de seu modo de expressar-se, de seus comportamentos e de seus valores, têm direito de viver em paz e der ser tais como são. Significa também que ninguém deve impor suas opiniões a outrem (KUNSCH; FISCHMANN, 2002, p. 157-158).

50 "A coexistência pacífica, porém, pode assumir formas políticas muito diferentes, com diferentes implicações para a vida moral cotidiana - isto é, para as interações concretas e envolvimentos mútuos de homens e mulheres. Nenhuma dessas formas é universalmente válida. Além da reivindicação minimalista do valor da paz com suas regras implícitas de transigência (que equivalem, grosso modo, à descrição-padrão dos direitos humanos básicos), não há princípios que regulem todos os regimes de tolerância ou que nos obriguem a agir em todas as circunstâncias, em todas as épocas e lugares, em nome de um conjunto particular de arranjos políticos ou constitucionais" (WALZER, 1999, p. 5). 
Humberto Giannini (1993, p. 17-18) afirma que:

Só pode ser tolerante, no sentido estrito, aquele que se comporta enquanto organismo e sistema. Se está disposto interiormente a acolher o estranho, o novo que o solicita, sem perder a essência de sua unidade e de sua identidade, ele será efetivamente tolerante.

O liame entre a tolerância e a intolerância é muito fino. Mesmo o Brasil, um País sem tradição de conflitos religiosos, registra o grave caso da Guerra de Canudos, marcado pela intolerância religiosa do Estado e de uma Religião contra um líder espiritual (Antônio Conselheiro).

Para André Glucksmann (2007, p. 126-127):

Quando a consciência mundial preconiza que a humanidade é uma e indivisível, qualquer sujeito incontrolável corre o risco incessante de ser uma lembrança de que foi preciso contar três, 1) os que perecem na câmara de gás, 2) os que os colocam dentro delas, 3 ) os que desviam o olhar e permitem que isso seja feito.

Infelizmente, a herança cultural da intolerância ainda é muito presente na sociedade, uma vez que, não podemos perder de vista que a defesa da tolerância se faz depois de séculos de intolerância e do uso indiscriminado da força e da violência por aqueles que deveriam professar e disseminar exatamente a paz e o amor universal.

A intolerância, como afirma Elie Wiesel (2000, p. 265), fomenta o ódio:

A intolerância está situada no começo do ódio. Ela assume aparências tão sutis que fica difícil discerni-la e combatê-la. E, no entanto, "se não a detivermos, será tarde demais". Uma vez instalada, gera inevitavelmente o desprezo, o ódio pelo outro; e o ódio, por sua vez, só gera o ódio.

A noção moderna de tolerância está intrinsecamente ligada à posição dos Estados acerca de uma neutralidade religiosa em seu cerne. Em outras palavras, quanto mais laico for o Estado e quanto mais professar a liberdade religiosa maior será a tolerância religiosa. 
Nesse sentido Norberto Bobbio (2002, p. 155) afirma:

A tolerância é um método que implica o uso da persuasão perante aqueles que pensam diferentemente de nós, e não o método da imposição. Desse ponto de vista, o laicismo ${ }^{51}$ é um dos componentes essenciais do mundo moderno, que até mesmo as religiões (e me refiro particularmente ao cristianismo) acabaram por aceitar. Tanto isso é verdade que em todas as Constituições modernas está afirmado o princípio da liberdade de religião, que é liberdade não apenas daqueles que professam uma religião, mas também daqueles que não professam nenhuma.

Esta é a posição de Claude Geffré (1993, p. 55-56) em relação à missão da tolerância ante as sociedades modernas:

Em relação às sociedades modernas, às sociedades democráticas, seria preciso fazer com que a Igreja não fosse dominadora nem marginal. Quero dizer que a Igreja deve renunciar a utilizar o poder secular, o Estado, para transmitir suas idéias, sua concepção de moral, etc. Por outro lado, a Igreja não pode tampouco aceitar tornar-se totalmente marginal, pois ela tem direito a uma expressão pública. [...] Os Estados que não respeitam a liberdade religiosa tampouco respeitam as outras liberdades: liberdade de associação, de reunião, de opinião, de educação, etc. É verdade que a Igreja tem um certo papel pedagógico em relação ao Estado, pois, na media em que pede ao Estado o respeito de sua liberdade de culto e de expressão, ela obriga também o Estado a levar em conta as outras liberdades que não estão separadas da liberdade religiosa, porque o fundamento mesmo da liberdade religiosa é a liberdade ética fundamental do homem, é sua liberdade de consciência.

${ }^{51}$ Laicismo nesse sentido proposto pelo autor, é compreendido por nós como laicidade, isto é, o Estado não aderir a nenhuma religião de forma oficial e permitir, constitucionalmente ou não a plena liberdade religiosa. 


\section{Conclusão}

O ódio e os conflitos derivados de problemas religiosos que temos atualmente são tão complexos que nem o esforço dos organismos internacionais em criar toda uma estrutura protetiva calcada nos Direitos Humanos é capaz de dirimir ou sanear os conflitos. O problema é a herança cultural que é atrelada e que não pode ser esquecida por parte das próprias religiões monoteístas, em especial, os conflitos promovidos pelos católicos na expansão do Cristianismo.

O desrespeito à religião alheia segue sendo um dos maiores problemas a ser enfrentado em questões ligadas à tolerância. Entretanto, uma religião que por quase trezentos anos realizou e fomentou a intolerância religiosa contra todos aqueles que se opunham à sua expansão territorial, cultural, política e social, como foi o caso da Inquisição cristã, produz um espólio, uma herança cultural negativa que o mundo do pós-guerra ainda não conseguiu dissociar e erradicar das agruras daquela época. Ao contrário, religiões orientais, como o Islamismo, aprenderam com os "ensinamentos" do Cristianismo e, com um viés notadamente político, fomentam a intolerância contra o mundo ocidental, em especial contra o capitalismo.

A disputa pelo poder mediante os líderes religiosos usando os fiéis como massa de manobra ocasionou um grande desastre à humanidade. A Igreja, seja ela católica, protestante, anglicana ou qualquer outra religião derivada, deve se calcar não mais em motivações políticas, mas sim, no que deveria ser o plano de metas fundamental desde o princípio dos tempos: o ser humano.

A tolerância pode representar a união dos povos e a elevação das pessoas em busca de uma comunhão universal. Esse é o caminho para a tolerância aliada aos conceitos atuais trazidos e viabilizados pelos Direitos Humanos. Enquanto se pensar em influenciar os demais, em um claro exemplo de proselitismo negativo, as religiões seguirão professando não a paz, mas sim, a intolerância e o caos no planeta.

O nosso escopo foi apresentar como que a religião pode ser o fio condutor tanto para o bem quanto para o mal da humanidade; resta saber quando os líderes religiosos começarão a aplicar na prática o que tanto divulgam como correto na 
teoria: a união dos povos, a fraternidade universal, a liberdade e a igualdade de todos perante Deus.

O caminho para a intolerância foi pavimentado pelas religiões ocidentais e culminou com a desgraça da intolerância, não religiosa, mas sim, da vida humana com a perda de 52 milhões de vidas em decorrência da Segunda Guerra Mundial. Já a pavimentação da tolerância ocorre dia após dia, em especial, após o surgimento e desenvolvimento dos Direitos Humanos, quando a defesa da vida humana, ou melhor, da dignidade da pessoa humana, passou a ser o elemento fulcral do debate da sociedade na segunda metade do século XX.

A linha que separa a tolerância da intolerância ainda segue muito tênue. $\mathrm{O}$ Direito desenvolveu uma série de elementos protetivos para os homens e para a coexistência pacífica. Que tudo o que ocorreu de negativo fomentado pela ambição política na religião seja exemplo para que, agora, em uma nova realidade e em um novo contexto histórico, a tolerância ocorra na prática.

E o primeiro passo a ser dado é combater o processo de intolerância em massa professado pelo Islamismo, para que se evite, assim, o novo cometimento de velhos erros como foi o caso dos cristãos. A laicidade, a tolerância, o respeito e a liberdade são os vetores neste cenário que prima pela liberdade de pensamento, credo, culto, consciência e, acima de tudo, existência.

\section{From religious intolerance to human rights}

\section{Abstract}

Religion is directly responsible for issues such as proselytizing, atheism and secularism. Therefore, understanding how relations were religions in ancient times will the framework of knowledge needed to provide religious intolerance professed and practiced largely by Western religions, especially. In this way, the religious freedom which today spreads and search through the protective elements of $\mathrm{Hu}$ man Rights is a direct result of historical evolution of religion itself, as well as its 
influence on people's lives and the power struggle between Church and State. The tolerance is the result of a whole construction of the international organizations in defense of human rights.

Keywords: Intolerance. Religion. Human Rights.

\section{Referências}

ALVES, José Augusto Lindgren. A arquitetura internacional dos direitos humanos. São Paulo: FTD, 1997.

ARENDT, Hannah. Responsabilidade e julgamento. Trad. Rosaura Eichenberg. São Paulo: Companhia das letras, 2004.

BAUBERÓT, Jean. Estratégias da liberdade. In: A tolerância por um humanismo herético. Trad. Paulo Neves. Porto Alegre: L\&PM, 1993.

BIGNOTTO, Newton. Tolerância e diferença. In: NOVAES, Adauto (Org.). Civilização e barbárie. São Paulo: Companhia das Letras, 2004.

BOBBIO Elogio da serenidade e outros escritos morais. Trad. Marco Aurélio Nogueira. São Paulo: UNESP, 2002.

BOBBIO, Norberto. A era dos direitos. Rio de Janeiro: Elsevier, 2004.

CASSAMANO, Marco Aurélio. Política e religião: o Estado laico e a liberdade religiosa à luz do constitucionalismo brasileiro. 2006. Tese (Doutorado na área de concentração de Direito, Estado e Sociedade) - Pontifícia Universidade Católica de São Paulo, São Paulo, 2006.

CÉSAR, Lucy Risso Moreira. Relacionamento igreja-mundo no Brasil contemporâneo. 1982. Dissertação (Mestrado na área de concentração de Ciências Humanas) - Pontifícia Universidade Católica de São Paul, São Paulo, 1982.

CHAIA, Miguel. Tolerância e liberdade: aforismos intempestivos. In: PASSETTI, Edson; OLIVEIRA, Salete (Coord.). A tolerância e o intempestivo. São Paulo: Ateliê Editorial, 2005. 
CHARLESWORTH, Max; INGPEN, Robert. Religiões no mundo. Trad. Elda Nogueira. São Paulo: Global, 2003.

COMPARATO, Fábio Konder. A afirmação histórica dos direitos humanos. 3. ed. São Paulo: Saraiva, 2003.

DELUMEAU, Jean; MELCHIOR-BONNET, Sabine. De religiões e de homens. Tradução de Nadyr de Salles Penteado. São Paulo: Ipiranga, 2000.

DEUS uma biografia. Revista Superinteressante, n. 284, p. 59, abr./2011.

DICIONÁRIO Houaiss da língua portuguesa. Rio de Janeiro: Objetiva, 2001.

FERRAZ JUNIOR, Tercio Sampaio. Introdução ao estudo do direito: técnica, decisão, dominação. São Paulo: Atlas, 2003.

FERREIRA, Pinto. Curso de direito constitucional. 9. ed. São Paulo: Saraiva, 1998.

FILOSOFIA e guerra. Revista Conhecimento Prático Filosofia, n. 26, p. 18.

FÜRST, Alfons. Ética da paz e disposição à violência: sobre a ambivalência do monoteísmo cristão em seus primórdios. In: FÜRST, Alfons. Paz na terra? As religiões universais entre a renúncia e a disposição à violência. São Paulo: Idéias \& Letras, 2009.

GEFFRÉ, Claude. A consciência obriga. In: . A tolerância por um humanismo herético. Trad. Paulo Neves. Porto Alegre: L\&PM, 1993.

GIANNINI, Humberto. Acolher a estranheza. In: A tolerância por um humanismo herético. Trad. Paulo Neves. Porto Alegre: L\&PM, 1993.

GLUCKSMANN, André. O discurso do ódio. Trad. Edgard de Assis Carvalho e Mariza Perassi Bosco. Rio de Janeiro: DIFEL, 2007.

GREEN, Toby. Inquisição: o reinado do medo. Trad. Cristina Cavalcanti. Rio de Janeiro: Objetiva, 2011.

GUERREIRO, Sara. As fronteiras da tolerância liberdade religiosa e proselitismo na Convenção Européia dos Direitos do Homem. Coimbra: Almedina, 2005.

HOUAISS, Antônio. Dicionário Houaiss da língua portuguesa. Rio de Janeiro: Objetiva, 2001. 
HUME, David. História natural da religião. São Paulo: Editora UNESP, 2005.

LAROUSSE. Grande Enciclopédia Larousse Cultural. São Paulo, 1998. v. 20.

LE GOFF, Jacques. As raízes medievais da intolerância. In: . A intolerância.

Trad. Eloá Jacobina. Rio de Janeiro: Bertrand Brasil, 2000.

LEFEBVRE, Georges. 1789: o surgimento da Revolução Francesa. Trad. Cláudia Schilling. 2. ed. São Paulo: Paz e Terra, 2011.

LEPEINES, Wolf. A intolerância: terrível virtude. In: . A intolerância. Trad. Eloá Jacobina. Rio de Janeiro: Bertrand Brasil, 2000.

LOMÉNIE, E. Beau. A Igreja e o Estado: um problema permanente. São Paulo: Flamboyant, 1958.

MARKOVITS, Francine. Entre crer e saber. In: A tolerância por um humanismo herético. Trad. Paulo Neves. Porto Alegre: L\&PM, 1993.

O’DONNELL, Kevin. Conhecendo as religiões do mundo. São Paulo: Edições Rosari, 2007.

ODALIA, Nilo. A liberdade como meta coletiva. In: PINSKY, Jaime; PINSKY, Carla Bassanezi (Org.). História da cidadania. 5. ed. São Paulo: Contexto, 2010.

PAULO II, João. Carta do papa João Paulo II a D. Jean-Pierre Ricard, arcebispo de Bordéus e presidente da Conferência Episcopal Francesa. Disponível em: <http:// www.vatican.va/holy_father/john_paul_ii/letters/2005/documents/hf_jp-ii_ let_20050211_french-bishops_po.html>. Acesso em: 3 fev. 2011.

ROUANET, Luiz Paulo. Paz, justiça e tolerância no mundo contemporâneo. São Paulo: Edições Loyola, 2010.

SCARPI, Paolo. Egito, Roma, Grécia, Mesopotâmia, Pérsia e politeísmos: As religiões do mundo antigo. São Paulo: Hedra, 2004.

SENADO FRANCÊS. A Declaração dos Direitos do Homem e do Cidadão Disponível em: <http://www.senat.fr/lng/pt/declaration_droits_homme.html>. Acesso em: 3 fev. 2011.

VEYNE, Paul. Quando nosso mundo se tornou cristão. Trad. Marcos de Castro. Rio de Janeiro: Civilização Brasileira, 2010. 
WALZER, Michael. Da tolerância. Trad. Almiro Pisetta. São Paulo: M. Fontes, 1999.

WIESEL, Elie. Vade-Mecum: por uma luta contra a intolerância. In: - $A$ intolerância. Trad. Eloá Jacobina. Rio de Janeiro: Bertrand Brasil, 2000.

WOLOSZYN, André Luís. Terrorismo global: aspectos gerais e criminais. Porto Alegre: Est Edições, 2009.

ZENGER, Erich. Violência em nome de Deus: O preço necessário do monoteísmo bíblico. In: FÜRST, Alfons. Paz na terra? As religiões universais entre a renúncia e a disposição à violência. São Paulo: Ideias \& Letras, 2009. 


\section{Para publicar na revista Universitas Humanas, acesse 0 endereço eletrônico www.publicacoesacademicas.uniceub.br. Observe as normas de publicação, para facilitar e agilizar o trabalho de edição.}

